\title{
Deposit insurance in times of crises : safe haven or regulatory arbitrage?
}

Citation for published version (APA):

Kleimeier, S., Qi, S., \& Sander, H. (2015). Deposit insurance in times of crises : safe haven or regulatory arbitrage? Maastricht University, Graduate School of Business and Economics. GSBE Research Memoranda No. 026 https://doi.org/10.26481/umagsb.2015026

Document status and date:

Published: 01/01/2015

DOI:

10.26481/umagsb.2015026

Document Version:

Publisher's PDF, also known as Version of record

\section{Please check the document version of this publication:}

- A submitted manuscript is the version of the article upon submission and before peer-review. There can be important differences between the submitted version and the official published version of record.

People interested in the research are advised to contact the author for the final version of the publication, or visit the DOI to the publisher's website.

- The final author version and the galley proof are versions of the publication after peer review.

- The final published version features the final layout of the paper including the volume, issue and page numbers.

Link to publication

\footnotetext{
General rights rights.

- You may freely distribute the URL identifying the publication in the public portal. please follow below link for the End User Agreement:

www.umlib.nl/taverne-license

Take down policy

If you believe that this document breaches copyright please contact us at:

repository@maastrichtuniversity.nl

providing details and we will investigate your claim.
}

Copyright and moral rights for the publications made accessible in the public portal are retained by the authors and/or other copyright owners and it is a condition of accessing publications that users recognise and abide by the legal requirements associated with these

- Users may download and print one copy of any publication from the public portal for the purpose of private study or research.

- You may not further distribute the material or use it for any profit-making activity or commercial gain

If the publication is distributed under the terms of Article $25 \mathrm{fa}$ of the Dutch Copyright Act, indicated by the "Taverne" license above, 


\section{Maastricht University}

Stefanie Kleimeier, Shusen Qi, Harald Sander

Deposit Insurance in Times of Crises: Safe Haven or Regulatory Arbitrage?

RM/15/026

\section{GSBE}

Maastricht University School of Business and Economics

Graduate School of Business and Economics

P.O Box 616

NL-6200 MD Maastricht

The Netherlands 


\title{
Deposit Insurance in Times of Crises: Safe Haven or Regulatory Arbitrage?
}

\author{
Stefanie Kleimeier ${ }^{\mathrm{a}, \mathrm{b},{ }^{*}, \text { Shusen }} \mathrm{Qi}^{\mathrm{a}}$, Harald Sander ${ }^{\mathrm{c}, \mathrm{d}}$ \\ ${ }^{a}$ Maastricht University, School of Business and Economics, Tongersestraat 53, 6211 LM Maastricht, \\ The Netherlands \\ ${ }^{b}$ University of Stellenbosch Business School, Carl Cronjé Drive, Bellville 7530, Cape Town, South \\ Africa \\ ${ }^{\mathrm{C}}$ Cologne University of Applied Sciences, Faculty of Economics and Business Administration, \\ Claudiusstraße 1, 50678 Köln, Germany \\ ${ }^{d}$ Maastricht School of Management, Endepolsdomein 150, 6229 EP Maastricht, The Netherlands
}

\begin{abstract}
This paper examines the impact of deposit insurance (DI) schemes on bilateral crossborder deposits. Our results suggest that not only the existence of explicit DI, but also DI design features, which reflect its credibility have an impact on cross-border deposits, and that the relative differences between reporting and depositor countries also matter. More importantly, in times of crises, depositors rely more on DI in general, but DI acts primarily as a "Safe Haven" rather than enabling "Regulatory Arbitrage". During the global financial crisis of 2008/09 the emergency actions of bank country governments, which supply and maintain these safe havens, have led to substantial relocations of cross-border deposits.
\end{abstract}

Keywords: Deposit Insurance; Cross-border deposits; Systemic banking crises; Gravity model JEL codes: F34; G18

* Corresponding author. Email: s.kleimeier@maastrichtuniversity.nl 


\section{Introduction}

Until the 2008/09 financial crisis, cross-border depositing increased rapidly not only in the interbank market, but also in the retail market. After a short period of retrenchment during the crisis, crossborder depositing started growing again and by September 2014 rose to US\$26 trillion, of which US\$8 trillion constitute cross-border liabilities to non-banks. ${ }^{1}$ Global deregulation, regional integration initiatives such as the introduction of the euro and the elimination of capital controls in many developing countries enabled banks to expand cross-border financial services rapidly. For customers, foreign deposit markets offer not only return opportunities and product diversity but foreign deposit insurance (DI) schemes also provide cross-border depositors with an opportunity for regulatory arbitrages and access to a safe haven, especially during financial crises. This paper provides an in-depth investigation of the relationship between cross-border retail depositing and national DI schemes in tranquil and crisis times. By evaluating the impact of the emergency actions taken during the 2008/09 global financial crisis, we also provide a unique analysis of the impact of crisis policies on cross-border banking.

The existence of a DI can make a banking market more attractive to cross-border depositors in two ways: First, depositor's funds are guaranteed by the DI agency. Second, a DI scheme may contribute to a more stable banking system by preventing bank runs as argued by Diamond \& Dybvig (1983). However, this effect is disputed as moral hazard can induce banks to engage in riskier activities thereby increasing the likelihood of a banking crisis (Demirgüç-Kunt \& Detragiache, 1997, 2002; Rossi, 1999). The empirical literature does not yet offer any unambiguous evidence on the relevance of DI for cross-border depositing. For example, Lane \& Sarisoy (2000) examine the relationship between an explicit DI and several measures of private capital inflows to developing countries but find no significant link. However, their measures of capital inflows are mainly composed of funds that are not insured. ${ }^{2}$ Huizinga \& Nicodème (2006) focus more closely on international liabilities including deposits. ${ }^{3}$ While they find that non-bank external liabilities increase after introduction of an explicit DI, they do not find any role for specific DI features. Similar to Lane \& Sarisoy (2000), their results are at least in part driven by the inclusion of uninsured liabilities. Furthermore, due to the aggregate level of their data at the bank country level, they are only able to

\footnotetext{
${ }^{1}$ As reported by the Bank of International Settlements' Locational Banking Statistics.

${ }^{2}$ Lane \& Sarisoy (2000) focus on developing countries in 1990 s and analyse gross private capital flows, net private capital flows, international syndicated loans and international bond issues.

${ }^{3}$ Huizinga \& Nicodème (2006) focus on developed countries from 1983 to 1999 and analyse the impact of the existence of an explicit DI scheme on external liabilities. Their data differentiate interbank and non-bank liabilities and originate from the BIS's International Banking Statistics. Note however that (1) interbank liabilities are generally not insured and (2) non-bank liabilities include insured deposits but also a certain amount of uninsured funds.
} 
investigate whether a DI system makes a given country more attractive to all foreign depositors in general.

By contrast, our paper employs a uniquely suitable data set of bilateral cross-border retail deposits provided confidentially by the Bank of International Settlements (BIS). Our data are based on the BIS's Locational Banking Statistics and cover cross-border deposits between 168 depositor countries and 24 bank countries for the period from 1998 to 2011 . We are - to the best of our knowledge - the first to use such a detailed dataset and are therefore able to contribute to the understanding of the role of DI schemes for cross-border depositing in numerous ways. First, our study extends the literature by analyzing retail deposits, e.g. deposits of households and nonfinancial corporations that are actually covered by DI schemes. As such, we can investigate the direct insurance effects and do not need to make any interference about the implications of DI systems on financial systems. Second, we investigate not only the attractiveness of the bank countries' DI, but also the importance of DI differences between the depositor's home country and the bank country. Analyzing the role of bank countries' regulations builds on the existing literature and inquires whether DI provides a "Safe Haven". The analysis of DI differences across countries adds to the literature and is informative about "Regulatory Arbitrage". Third, we investigate not only the effect of an explicit DI but also consider its specific features. As argued by Eisenbeis \& Kaufman (2015) the effectiveness of a DI depends crucially on its design and implementation. Despite deposit market internationalization, significant heterogeneity still exists across national DI schemes ${ }^{4}$ potentially increasing the relative attractiveness of a deposit market. As our analyses will cover regulatory differences across countries we can provide in-depth insights into which features of a DI can induce regulatory arbitrage. ${ }^{5}$ Fourth, we provide an analysis of the potentially changing importance of safe havens and regulatory arbitrage during stable versus crisis times using the Laeven \& Valencia (2008, 2010, 2012) financial crisis database. Here we build on Kleimeier, Sander, \& Heuchemer (2013) who find that during systemic banking crises, depositors discipline their home banking system by relocating deposits to foreign safe havens. ${ }^{6}$ Fifth and finally, we investigate the impact and efficiency of emergency actions taken by many countries in response to the severity of the 2008/09 crisis,

\footnotetext{
${ }^{4}$ See Dale, Bruni, \& De Boissieu (2000), Eisenbeis \& Kaufman $(2006,2008)$.

${ }^{5}$ We thereby contribute indirectly to the literature on DI design including optimal DI schemes and implications on the banking systems and financial markets. See Garcia (1999), Demirgüç-Kunt \& Sobaci (2001), DemirgüçKunt \& Detragiache (2002), Demirgüç-Kunt, Karacaovali, \& Laeven (2005), Hoelscher, Taylor, \& Klueh (2006), Laeven \& Beck (2006), Demirgüç-Kunt, Kane, \& Laeven (2014).

${ }^{6}$ Kleimeier et al. (2013) build on the literature on the disciplining role of (domestic) depositors pioneered by Berger (1991). Later contributions e.g. report evidence for a "flight to quality (safety) by depositors" during the Asian crisis of 1997/08 (Ding, Domac, \& Ferri, 1998). Rochet (2004) reports empirical evidence for direct market discipline in crisis periods when depositors are able to "vote with their feet". Park \& Peristiani (1998) and Martinez Peria \& Schmukler (2001) find similar effects during the banking crises in USA in the 1980s, and Argentina, Chile, Mexico in the 1980s and 1990s, respectively.
} 
which included explicit and often enhanced government guarantees over and above the regular DI coverage. We find that both, the quest for safe haven and regulatory arbitrage are important drivers of cross-border depositing in stable times. Conversely, in times of financial crisis, it is mainly the safe haven motive that dominates. This safe haven motive is particularly important during the financial crisis of 2008/09. We also provide evidence that the emergency actions taken in bank countries, in particular the introduction of government guarantees, are major drivers of global retail deposit relocations towards safe havens.

The plan of the paper is as follow. In section 2 we develop our gravity model for analyzing the impact of DI on cross-border deposits by formulating five hypotheses and the corresponding specifications of the gravity model. Section 3 details the various extensive databases we are using. Section 4 reports the results. Section 5 concludes.

\section{A Gravity Model of Cross-Border Deposits}

We apply a gravity model framework to empirically analyze the impact of DI on bilateral crossborder deposits. Based on Tinbergen (1962) and Pöyhönen (1963), the gravity model has been proven successful in explaining international trade and, in its basic form, explains bilateral trade with the trading partners' economic masses and geographical distance (Krugman, 1980; Helpman \& Krugman, 1985; Baltagi, Egger, \& Pfaffermayr, 2003). Later studies extend this basic model to capture additional bilateral characteristics more precisely, including joint trade agreements, common currency membership, or cultural distance (Baxter \& Kouparitsas, 2006). In line with Portes \& Rey (2005), who argue that gravity model could at least work as well in explaining asset trades as good trades, gravity modelling has more recently extended to the realm of international finance as well (Lane \& Milesi-Ferretti, 2008; Martin \& Rey, 2004; Buch, 2005; Portes \& Rey, 2005; Aviat \& Coeurdacier, 2007; Buch \& Lipponer, 2007; Coeurdacier \& Martin, 2009; Okawa \& Van Wincoop, 2012; Kleimeier et al., 2013, 2014; Sander, Kleimeier, \& Heuchemer, 2013). The bilateral character of the dependent variable makes the gravity approach the model of choice to analyze both, the safe haven behavior and, in particular, regulatory arbitrage behavior.

We start with the investigation of safe haven behavior and employ the following gravity model that tests the relationship between DI schemes in the bank countries and cross-border deposits:

$$
\operatorname{Dep}_{i j t}=\alpha_{i j}+\alpha_{i}+\alpha_{j}+\alpha_{t}+\beta_{1} D I_{i t}+\beta_{2} \operatorname{size}_{i j t}+\delta X_{i j t}+\varepsilon_{i j t}
$$


where $D e p_{i j t}$ are the exchange rate adjusted stocks of cross-border deposits from depositors in country $\mathrm{j}$ to banks in country $\mathrm{i}$ in year t. Size ${ }_{i j t}$ refers to the economic masses of bank country $\mathrm{i}$ and depositor country $\mathrm{j}$ in year $\mathrm{t}$, which equals to the sum of logarithmic GDP of the two countries. $X_{i j t}$ represents other control variables commonly used in gravity models, including proxies for banking market size, de facto and de jure openness (e.g. bilateral trade and a globalization index), currency unions and free trade agreements. Following Baldwin \& Taglioni (2006) and in accordance with Bekaert, Harvey, Lundblad, \& Siegel (2013) we use a full set of country pair, bank country, depositor country and year fixed effects given by $\alpha_{i j}, \alpha_{i}, \alpha_{j}$ and $\alpha_{t}$, respectively. Our focus does not lie on the general determinants of international deposits. Thus, instead of adding controls for transactional frictions such as geographical and culture distance, legal origin and common language ${ }^{7}$, we employ country pair fixed effects to control for all these time-invariant variables that may affect crossborder deposits. Country pair fixed effect can control bilateral trade resistance which is the size of the barriers to trade between countries $i$ and j. In addition, we follow James \& Van Wincoop (2003) and include bank and depositor country fixed effects to control multilateral trade resistance, which refers to the barriers which each country $i$ and $j$ faces in their trade with all their trading partners (including domestic and internal trade). Finally, we employ year fixed effects to control for common time-varying factors. $D I_{i t}$ is our variable of interest and captures the different features of the bank country's DI scheme. In its simplest form, it represents a dummy variable equal to 1 when an explicit $\mathrm{DI}$ exists in the bank country $\mathrm{i}$ in year $\mathrm{t}$ but we also explicitly measure various design features of the DI scheme in the bank countries.

We postulate that depositors are attracted to a given bank country when its DI provides depositors with a safe haven. As banks transform deposits into risky loans and other risky assets, depositors are exposed to the bank's credit risk. However, depositors prefer to reduce or even eliminate their exposure to bank risk and thus value the protection provided by DI. However, only a well-designed DI scheme can provide depositors with effective risk reduction and avoid moral hazard problems (Diamond \& Dybvig, 1983, 1986; Merton \& Thakor, 2015). As such, specific features of the DI scheme such as coverage ratio, DI funding or power of the DI agency should matter to depositors. These considerations lead to our first hypothesis:

\footnotetext{
${ }^{7}$ Regarding specific determinants of cross-border deposits, Grilli (1989) finds that non-bank deposits are driven by interest taxes and bank secrecy, while interbank deposits are determined by dividend taxes and economic size. Alworth \& Andresen (1992) use a gravity model to explain cross-border deposits with reserve ratios. Huizinga \& Nicodème (2004) find a weak linkage between bilateral bank liabilities held by non-banks and income taxes. Heuchemer, Kleimeier, \& Sander (2009) find that cultural factors act as barriers to crossborder depositing in the Eurozone.
} 


\section{H1: Safe Haven Hypothesis}

Compared to bank countries without an explicit DI, the existence of an explicit DI makes a bank country more attractive for cross-border depositors. In addition, the attractiveness of a bank country for cross-border depositors increases with the strength of its DI scheme relative to the strength of other bank countries' DI schemes.

As countries also have their own freedom to design their DI schemes, this provides room for international regulatory competition and thus for regulatory arbitrage by depositors. Specifically, the differences in DI schemes between bank and depositor countries may matter in a relative way, with the DI system in the depositor country serving as a benchmark. Thus, besides the absolute quality of a DI system in the bank country, depositors may also care about the relative quality of a DI system in the bank country, taking into account other variables such as physical and cultural proximity or the existence of joint trade agreements or a joint currency. This leads to our second hypothesis.

\section{H2: Regulatory Arbitrage Hypothesis}

The existence of an explicit DI makes a bank country attractive for cross-border depositors from countries that lack an explicit DI. In addition, the attractiveness of a bank country for cross-border depositors increases with the strength of bank country's DI scheme relative to the strength of depositor country's DI scheme.

In order to test the Regulatory Arbitrage Hypothesis, we adjust model (1) to allow for the differences in DI schemes across bank and depositor countries, as shown by $D I_{i j t}$ below.

$$
\operatorname{Dep}_{i j t}=\alpha_{i j}+\alpha_{i}+\alpha_{j}+\alpha_{t}+\beta_{1} D I_{i j t}+\beta_{2} \text { size }_{i j t}+\delta X_{i j t}+\varepsilon_{i j t}
$$

But do the effects postulated in the Safe Haven and Regulatory Arbitrage Hypotheses hold when the depositor experiences a banking crisis at home ${ }^{8}$, and if so, which effects are more pronounced? For instance, depositors from countries that are undergoing a systemic banking crisis may search for a better DI abroad either in the relative sense of regulatory arbitrage or in the absolute sense of a safe haven. However, it may also be possible that depositors totally lose faith in

\footnotetext{
${ }^{8}$ We would also like to investigate what happens when a bank country experiences a crisis. As described in the next section, our sample period covers 1998 to 2011 and covers 24 bank countries and 168 depositor countries. However, we observe systemic banking crises only in depositor countries with a single exception: The 2008/09 crisis also affected bank countries. Due to its unique features, i.e. the fact the countries adjusted their DI schemes in response to the crisis, we will study the 2008/09 crisis separately in the context of our Emergency Actions Hypothesis.
} 
the banking sector and its DI and as a result the relationships between DI and cross-border depositing diminishes or even disappears. Thus we formulate two hypotheses with respect to financial crisis in depositor countries:

\section{H3: Safe Haven in Crisis Hypothesis}

The importance attributed by cross-border depositors to the existence and strength of the bank country's DI increases when depositors experience a banking crisis at home.

\section{H4: Regulatory Arbitrage in Crisis Hypothesis}

The importance attributed by cross-border depositors to the existence and strength of the bank country's DI relative to the depositor country's DI increases when depositors experience a banking crisis at home.

To test these hypotheses, we estimate the following two regressions, with model (3) focusing on the bank country features and thus testing the Crisis Hypothesis in the context of our save haven argument and model (4) focusing on the differences across countries and thus testing the Crisis Hypotheses in the context of regulatory arbitrage:

$$
\begin{aligned}
& \operatorname{Dep}_{i j t}=\alpha_{i j}+\alpha_{i}+\alpha_{j}+\alpha_{t}+\beta_{1} D_{i t} * \text { stable }_{j t}+\beta_{2} \text { DI }_{i t} * \text { crisis }_{j t}+\beta_{3} \text { size }_{i j t}+\delta X_{i j t}+\varepsilon_{i j t} \\
& \operatorname{Dep}_{i j t}=\alpha_{i j}+\alpha_{i}+\alpha_{j}+\alpha_{t}+\beta_{1} D_{i j t} * \text { stable }_{j t}+\beta_{2} D I_{i j t} * \text { crisis }_{j t}+\beta_{3} \text { size }_{i j t}+\delta X_{i j t}+\varepsilon_{i j t}
\end{aligned}
$$

where stable $e_{j t}$ is a dummy variable equal to 1 when there is no systemic banking crisis in depositor country $\mathrm{j}$ in year t. Similarly, crisis $_{j t}$ is a dummy variable equal to 1 when there is a systemic banking crisis in depositor country $\mathrm{j}$ in year $\mathrm{t}$. An insignificant $\beta_{2}$ implies that DI does not matter for crossborder depositors during a crisis. Similarly, if $\beta_{2}$ is significantly smaller than $\beta_{1}$ or has the opposite sign, a banking crisis destroys the faith in DI systems and thus diminishes or even eliminates the relationships. However, a $\beta_{2}$ that is significantly larger in absolute values and has the same sign as $\beta_{1}$ suggests that depositors trust foreign DI schemes during crises, which supports either the Safe Haven in Crisis Hypothesis or Regulatory Arbitrage in Crisis Hypothesis or both.

The two crisis hypotheses as outlined above are applicable to the majority of historic banking crises as these are country specific. The 2008/09 banking crisis which started in the US is however different as it spilled over into numerous countries and became an almost global crisis. In response to the severity of the crisis, many countries revised their DI schemes. According to 
International Association of Deposit Insurers (IADI), at least 49 countries enhanced depositor protection, including 20 countries with maximum coverage increases (e.g. full guarantees), 22 countries with permanent coverage increases and seven countries with temporary coverage increases. These actions were initiated in Europe but quickly spread to nearly every continent, e.g. most revisions took effect between September 2008 and March 2009. These emergency actions to enhance DI systems provide us with a great opportunity to more specifically examine how the changing design features of DI impact cross-border deposits. Before the 2008/09 crisis, the main goal of DI agencies was protecting small depositors, as they did not have the ability to understand and monitor the risks taken by financial institutions. However, after the crisis, maintaining and strengthening the stability of the financial system has been set as the primary goal delegating the protection of small depositors to secondary importance (Bernet \& Walter, 2009). Thus our fifth and final hypothesis postulates the following:

\section{H5: Emergency Actions Hypothesis}

The emergency actions taken by the bank country regarding its explicit DI ensure that the bank country remains an attractive safe haven for cross-border depositors.

To empirically test this hypothesis, we will employ a difference in difference analysis within our gravity model setting:

$$
\text { Dep }_{i j t}=\alpha_{i j}+\alpha_{i}+\alpha_{j}+\alpha_{t}+\beta_{1}(\text { emergency action } * 2008 / 09 \text { crisis period })_{i t}+\beta_{2} \text { size }_{i j t}+
$$

where emergency action is a dummy variable equal to 1 if a bank country adopted various emergency actions to enhance its $\mathrm{DI}$, and 0 otherwise. These emergency actions include an explicit DI Introduction or the provision of an official government guarantee, limited government guarantee or unlimited government guarantee. 2008/09 crisis period is a dummy variable equal to 1 for the period from 2008 to 2011 when emergency actions are taken. Our model already includes bank country fixed effects and year fixed effects, thus the separate effects of these two variables are already included. $\beta_{1}$ represents the treatment effect, which measure the impact of these emergency actions on cross-border deposits. 


\section{Data}

Our paper is -to the best of our knowledge- unique in that it utilizes all major recent databases on global DI in a systematic manner and investigate their effects on cross-border retail depositing using a unique, custom made, confidential, and bilateral country-level data set provided by BIS. Using bilateral data allows us to examine cross-border depositing for all pairs of bank and depositor countries. ${ }^{9}$ Furthermore, we only consider non-bank deposits, which are mainly held by individuals and businesses as DI schemes tend to only cover non-bank deposits but exclude interbank deposits from coverage. The BIS Locational Banking Statistics are perfectly suited to analyze such crossborder banking activities as they are compiled using principles that are consistent with balance of payments and thus the principle of residence. However, the publicly available data can only be disaggregated either by bank country or by depositor country, instead of being disaggregated bilaterally by both at the same time. Therefore, our paper uses a customized and confidential data set made available by BIS, which exactly provides this bilateral disaggregation. Although the BIS Consolidated Banking Statistics publicly provide bilateral data, these data only report foreign claims and not deposits. Furthermore, the consolidated data are based on the principle of nationality instead of residence. In conclusion, the BIS Locational Banking Statistics are preferable.

Our sample covers 24 bank countries ${ }^{10}$ and 168 depositor countries from 1998 to 2011 but not all bilateral cross-border deposits $X_{i j t}$ are available for all years. As such our panel is unbalanced. When testing the Safe Haven, Regulatory Arbitrage and Crisis Hypotheses, we only consider a sample period from 1998 to 2007. When testing the Emergency Actions Hypothesis, we rely on a sample period of 1998 to $2011 .{ }^{11}$ The BIS reports unadjusted stocks and exchange rate adjusted flows of cross-border deposits. In order to eliminate any potential exchange rate valuation effects, we calculate annual exchange rate adjusted stocks by taking the initial nominal stocks and successively adding the exchange rate adjusted flows. Figure 1 provides a first impression of the evolvement of

\footnotetext{
${ }^{9}$ A cross-border deposit occurs when a bank in one country receives a deposit from a depositor who resides in another country. Specifically, our definition is based on the residence and not the nationality of the bank and depositor. For instance, a cross-border deposit is made when a depositor who resides in country A deposits money at an institution (i.e. subsidiary or branch) of a bank that is located in country B, independent of where the head-quarter of the bank is located. In comparison, domestic deposits are made when residents of country $B$ deposit money with a bank that is located in country B. Thus, we are exactly examining those cases where a depositor crosses a national border.

${ }^{10}$ Australia, Austria, Belgium, Brazil, Canada, Chile, Denmark, Finland, France, Germany, Greece, India, Ireland, Italy, Luxembourg, Macao SAR, Netherlands, Panama, Portugal, Spain, Sweden, Switzerland, United Kingdom, United States.

${ }^{11}$ Our full data set for cross-border deposit covers 1995-2011, however, the DI data set only start from 1998, and during the 2008/09 financial crisis, many emergency actions have been taken to enhance the DI schemes, both permanently and temporarily. Thus we end our first sample in 2007, and analyze the impact of these emergency actions in 2008 in the following section. Another reason to end our first sample period in 2007 is that before the 2008/09 financial crises, systemic banking crises only occurred in the customer countries, not in reporting countries, in our BIS sample. Thus leaving out the post-2007 period enable us to separate the "old" crises to the "new", which is more complicated and also occurred in the reporting countries in our sample.
} 
cross-border deposits over time. Both unadjusted and adjusted stocks show high growth from US\$1.3 trillion in 1998 to around US\$5 trillion in 2008 before dropping by as much as $25 \%$ as a consequence of the $2008 / 09$ banking crisis. Importantly, about $16 \%$ of the deposit stock volume in 2008 can be attributed to exchange rate valuation effects. Therefore, it is necessary and important to adjust for exchange rate valuation effects. Furthermore, our sample is quite heterogeneous as it covers a wide range of countries with different levels of economic and financial development. Figure 2 plots the total annual volume of cross-border deposits that a given bank country receives from all depositor countries, averaged across years. Figure 2 reveals how substantial the differences across countries are. In the average year, Chile receives the least cross-border deposits, amounting to only US\$182 million from all depositor countries combined. In contrast, banks in the United Kingdom receive the most cross-border deposits amounting to US\$617 billion.

\section{[Insert Figures 1 and 2 about here]}

Data on DI schemes are a combination of the Cross-Country Deposit Insurance Database by Demirgüç-Kunt \& Sobaci (2001), Demirgüç-Kunt et al. (2005) and Demirgüç-Kunt et al. (2014); the Bank Regulation and Supervision Database by Barth, Caprio, \& Levine (2001) and Cihak, DemirgüçKunt, Martinez Peria, \& Mohseni-Cheraghlou (2012) as well as the Deposit Insurance Index Database by Barth, Caprio, \& Levine (2013). The main data source that we rely on is 'Chapter 8: Depositor (Savings) Protection Schemes' in the Bank Regulation and Supervision Database due to its indicator consistency and higher survey frequency. Regarding indicator consistency, we are able to not only measure $D_{j t}$ and $D_{i j t}$ as the existence of an explicit DI but are also able to obtain proxies for specific DI characteristics. Regarding the survey frequency, we fill the gap between two consecutive surveys. Specifically, 1998-2001 is filled with data in the survey that was started in 1998. Similarly, 2002-2005 and 2006-2007 are filled with data from the surveys that were conducted in 2002 and 2006 respectively. We only expand the survey data forward so that cross-border deposits are regressed on pre-determined designs of DI systems.

Our proxies for specific DI characteristics capture the insurance benefits for the depositor as well as the moral hazard problem introduced by a poorly designed DI scheme. As argued by Barth, Caprio, \& Levine (2004), the existence of a DI can induce banks to increase their risk taking and a moral hazard problem arises when risk levels become excessive. However, a DI scheme can be designed to limit moral hazard for example by introducing coinsurance or risk-based insurance fees. We consider the existence of an explicit DI, the DI power and DI moral hazard mitigation as core 
features of a DI scheme and will thus focus on them in our empirical analyses. However, we will also report results for various individual DI features. ${ }^{12}$

Among the three core DI proxies, the existence of an explicit $D I$ is our most fundamental measure. It is defined as a dummy variable equal to one if a bank country has an explicit DI in place and zero if no or only an implicit DI exists in the bank country. Next, we include Barth et al. (2004) DI power measure. This index considers whether the DI agency has the power to make the decision to intervene in a bank or takeover a troubled bank, has the power to take legal action against bank directors or officials, or has ever taken any legal action against bank directors or officers. The index ranges from zero to four, depending on whether the DI agency has none or all three of these powers. A DI agency without these powers might be ineffective, i.e. in cases of political interference or weak relationships between DI agency and the bank supervisors, who instead of the DI agency have the power to resolve bank failures (Garcia, 1999). Finally, we combine some of the individual DI proxies to generate a DI moral hazard mitigation index. Here we follow Demirgüç-Kunt \& Detragiache (2002) and consider whether a DI scheme is funded by the government, the bank or both, whether the insurance fees charged to banks vary based on risk assessment, or has formal coinsurance. In each case, a value of one is assigned such that the DI moral hazard mitigation index can range from 0 to 3 . Higher values imply greater ability to mitigate moral hazard. This index is based on individual DI features which fall into four different categories.

Regarding the specific DI characteristics, we first consider several measures of the size of the DI coverage from the perspective of the depositor. The coverage ratio reflects the DI's coverage limit divided by the per capita GDP in the bank country. Limit per person is measured as a dummy variable equal to one if the DI scheme imposes insurance limit per depositor, and zero otherwise. Coinsurance is a dummy variable equal to one if formal coinsurance by the depositor is part of the DI scheme, and zero otherwise. Under coinsurance, only a certain percentage of the value of a deposit is covered while the remainder is uninsured and can potentially be lost in case of bank failure. Foreign currency coverage is a dummy variable equal to one if the DI scheme covers not only domestic but also foreign currency deposits, and zero otherwise. Additional compensation is a dummy equal to one if uninsured depositors were compensated from the DI guarantee fund the last time a bank failed. While a high degree of coverage is beneficial to depositors, it also increases moral hazard. As argued by Garcia (1999), limited or restricted DI coverage reduces moral hazard as large, sophisticated depositors remain uninsured and thus have an incentive to monitor and discipline banks by demanding higher deposit rates or refusing to deposit funds altogether.

\footnotetext{
${ }^{12}$ Detailed variable definitions and sources are provided in Table A1 of the Appendix.
} 
Second, we consider the extent of DI coverage from the perspective of the banking system as a whole. The uninsured ratio indicates the fraction of banks' large denominated debt liabilities relative to total assets that are definitely not covered by any explicit or implicit savings protection scheme. Insured funding measures the percent of the commercial banking system's assets that are funded with insured deposits.

Third, we utilize a DI's funding source index. This index is set to 1 if the DI scheme is funded by banks only, to 2 if it is jointly funded by banks and the government, and to 3 if it is funded by the government only. Demirgüç-Kunt \& Detragiache (2002) argue that moral hazard is stronger under government funding but weaker under bank funding as banks do not bear the cost of their moral hazard. Thus, an increasing value in the funding source index indicates stronger moral hazard.

Fourth, compulsory participation is a dummy equal to one if participation in the deposit insurance system is compulsory for banks, and zero otherwise. Compulsory participation is important to avoid adverse selection in particular when DI premia are not risk adjusted. In this case, the strongest banks have the most incentive to withdraw from the DI leaving only the weakest bank as DI members (Garcia, 1999). Even without risk-based DI premia, compulsory participation eliminates this adverse selection problem and thus leads to a stronger DI scheme.

DI schemes change over time even before 2008 and vary across countries as the summary statistics in Table A2 of the Appendix indicate. In general, countries might provide implicit deposit insurance or increase existing insurance in times of banking crisis or failures. In particular, during the 2008/09 financial crisis, many countries responded by quickly taking emergency actions in 2008 . All emergency actions enhance DI coverage. The data are taken from DI around the world dataset by Demirgüç-Kunt et al. (2014) and in line with the IADI's categorization, we differentiate between the introduction of an explicit DI and the provisions of a government guarantee, regardless of the guaranteed amount. Demirgüç-Kunt et al. (2014) cover 22 out of our 24 bank countries. Among them, 16 countries have undergone the 2008/09 financial crisis. These countries plus Australia introduced explicit DI on October $12^{\text {th }}, 2008$. Six countries (namely Australia, Austria, Denmark, Germany, Ireland and the United States) announced official guarantees on deposits, of which Germany and United States set a limited guarantee, while the other four countries provide an unlimited guarantee.

To test the effects of crises on cross-border deposits, we employ the Systemic Banking Crises Database by Laeven \& Valencia (2008) which identifies three types of crises, namely banking, currency and sovereign debt crises. A banking crises is defined as a situation where "a country's corporate and financial sectors experience a large number of defaults and financial institutions and corporations face great difficulties repaying contracts on time. As a result, non-performing loans 
increase sharply and all or most of the aggregate banking system capital is exhausted". We consider all systemic banking crises during our sample period, that is, 1998-2007. Table A3 in the Appendix shows the frequency of banking crises over time and indicates that banking crises are more frequent in 1998-1999 which at least partly reflects the Asian crisis. During the following years, the number of systemic banking crises fluctuates on a relatively low level. As the Systemic Banking Crises Database also includes information on the starting and ending year of the systemic banking crises that enables us to cover not only the start of the crises, but also the whole period of it.

Finally, we include a set of control variables that are specific for the bank and borrower country pair and vary over time. Size $e_{i j t}$ is based on the total GDP of both countries obtained from the World Bank's World Development Indicators Database. From the IMF's International Financial Statistics we obtain our proxy for credit, e.g. the size of the banking market measured as the two countries' aggregate domestic credit to the private sector as percent of GDP. We employ three measures of openness. First, the $K O F_{i j t}$ Index of Globalization serves as a proxy for de jure openness. Second, we measure de facto openness via trade which reflects the imports and exports between the bank and depositor country and is obtained from the STAN Database. Third, we include a dummy variable set to one if both countries belong to the same free trade area (FTA). We also control for exchange rate risk by coding a dummy variable equal to one if the bank and depositor country belong to the same currency union. FTA and currency union data are obtained and updated from Sander et al. (2013) and Kleimeier et al. (2014) with the original definitions following Rose (2005) and Ilzetzki, Reinhart, \& Rogoff (2008), respectively.

\section{Results}

\subsection{Safe Haven and Regulatory Arbitrage in Cross-Border Depositing}

In this section we examine the impact of various DI designs on cross-border deposits. In addition, we assume that not only the design of the DI system in the bank country matters, but that also the differences in DI design between bank and depositor country matters. In other words, we investigate the Safe Haven and Regulatory Arbitrage hypotheses.

We start with the Safe Haven Hypothesis by investigating the impact of the existence of an explicit DI in the bank country, its moral hazard and power on cross-border deposits based on our gravity model of equation (1). Results are shown in Panel A of Table 1. Regressions (1) to (3) provide a parsimonious specification in which we only control for size in addition to our various fixed effects. The specification of regressions (4) to (6) is more profligate with a more complete set of control variables. As during our sample period, explicit $D I$ does not change over time for any given bank country, we can only include depositor country and year fixed effects in regressions (1) and (4). In 
regression (1), the impact of an explicit $D I$ is highly significant and - as expected - positive, indicating that bank countries with an explicit DI attract more cross-border deposits than bank countries without an explicit DI. Results regarding the DI agency's power and actions taken to mitigate moral hazard in the DI systems affect cross-border deposits are reported in regressions (2) and (3) and indicate that more deposits flow to countries whose DI agency have more power or take more actions to mitigate moral hazard. ${ }^{13}$ Our results are not only statistically significant but also economically relevant. For example, the introduction of an explicit DI is associated with a 4.5 fold increase in cross-border deposits. As the shift from an implicit or non-existence to an explicit DI constitutes a fundamental change in the country's banking system, such a substantial increase in cross-border deposits is not surprising. Furthermore, a one unit increase in the DI power and moral hazard mitigation increases cross-border deposits by $6.2 \%$ and $5.1 \%$ respectively. In regressions (4) to (6) we add more control variables but our DI results remain significant. ${ }^{14}$ Economically, the introduction of an explicit DI is now associated with a 3.5 fold increase in cross-border deposits, which is still substantial. ${ }^{15}$ Overall, our results are in line with our Safe Haven Hypothesis: The existence of explicit DI systems and the strength of the overall features of the DI schemes attract more cross-border deposits to that country.

We now continue to examine, whether the specific DI design features also matter. Results are reported in Panel B of Table 1. Regressions (1) to (5) and (10) to (14) focus on the different proxies of the DI coverage that are directly relevant to the depositor. Generally, depositors favor bank countries with DI schemes that provide a high level of insurance in terms of coverage ratio ${ }^{16}$ but deposit less in countries with formal coinsurance. Interestingly, besides the current DI designs, historical records of the DI systems are also important. The positive and significant coefficient of additional compensation implies that a bank country will attract more deposits if during the last bank failure, uninsured depositors were compensated from the deposit guarantee fund. Regressions (6), (7), (15) and (16) analyze the role of DI coverage from the perspective of the banking system as a whole. More insured funding is associated with more cross-border deposits, while the impact of the uninsured ratio is insignificant. So far, the results in Panel B indicate that depositors care about DI

\footnotetext{
${ }^{13}$ Similar to Huizinga \& Nicodème (2006), we also lag the DI variables to allow for the possibility that DI schemes may only affect cross-border deposits with a lag, because depositors may need time to relocate their deposits concerning a DI change. Results are shown in Table A4 of the Appendix and are robust.

${ }^{14}$ GDP coefficients are often not or only marginally significant because of the use of the full set of dummies. The other control variables generally show the expected coefficients indicating that cross-border deposits are higher when bank and depositor country are linked by trade flows, are member of the same FTA or share a common currency.

${ }^{15}$ It is important to note that the number of observations varies across regressions (1) to (3) and (4) to (6), respectively, due to the fact that bank countries do not necessarily participate in all three DI surveys and that even in the same survey, some countries may only answer part of the survey questions, resulting in various missing values in different DI measures.

${ }^{16}$ The coefficient in regression (10) just misses the $10 \%$ significance level.
} 
coverage of their own deposits, as well as the DI coverage of the banking system as a whole. The remaining regressions in Panel B focus on the potential DI-induced moral hazard and adverse selection problems in the bank country by including the funding source index and compulsory participation proxies, respectively. Only the former is significant in regression (8) indicating that depositors tentatively favor countries in which banks' moral hazard is limited as funding is mainly provided by banks. Although some of the specific DI features are insignificant in some regression specifications, the overall results support our Safe Haven Hypothesis: In addition to the existence of explicit DI, DI design features also affect the international location of non-bank deposits. Even if some specific DI features are not directly relevant, they matter in aggregate as depositors favor countries with a DI that induces less bank moral hazard as measured by our aggregate DI moral hazard mitigation proxy.

\section{[Insert Table 1 about here]}

So far we only examine how the DI systems in the bank countries would impact cross-border deposits. However, the differences in DI schemes between any pair of a bank country and a depositor country may also matter in a relative way. In this sense, the DI system in the depositor country may serves as a benchmark. Next to the absolute quality of the DI system in the bank country, depositors also care how much better the DI in the bank country is relative to their home country. To test for the Regulatory Arbitrage Hypothesis, we take differences of all the DI measures between all pairs of bank countries and depositor countries and regress cross-border deposits on these differences in DI schemes as indicated by model (2). Results are shown in Table 2. From Panel A we can conclude that depositors hold more funds in bank countries with better DI schemes than they can find in their home country. Specifically, depositors from countries without explicit DI tend to deposit their money in bank countries with explicit DI while depositors from countries with explicit DI are less likely to deposit their money in bank countries without explicit DI. Equally relevant in terms of statistical significance is the result that bank countries whose DI authorities have relatively stronger power than the DI authorities in the depositor countries attract more crossborder deposits. In contrast, the coefficients for moral hazard mitigation actions are insignificant. While results are overall in accordance with the Regulatory Arbitrage Hypothesis, it also becomes clear that regulatory arbitrage relies to a large extent on the relative power of the DI agency. ${ }^{17}$ Panel

\footnotetext{
${ }^{17}$ We again lag the DI variables and report results in Table A5 of the Appendix. Among our three DI proxies, lagged explicit DI and DI power proxies are significant stressing the importance of this DI feature for depositor's regulatory arbitrage behavior. In general, Tables A4 and A5 show that lagged DI variables are less significant, or at most equally significant, compared to contemporaneous DI variables. This suggests that the
} 
B shows the impact of country-pair differences in DI design features on cross-border deposits. However, only differences regarding additional compensation and DI's funding source are significant in both regressions with only size as control and with the full set of controls. Limit per person and insured funding are significant only in one of the regressions. In combination, the results from Panels $A$ and B indicate that regulatory arbitrage only occurs when the bank country's DI surpasses a minimum level of trustworthiness as indicated by the role of DI power and regulatory arbitrage is in general less important for depositors.

\section{[Insert Table 2 about here]}

\subsection{Cross-Border Banking and Home Country Banking Crisis}

In this section we investigate whether the relationships between DI schemes and cross-border deposits would change when bank countries experience a systemic banking crisis. Depositor country banking crises are modeled as indicated in equations (3) and (4) and reported in Table 3 and Table 4. In Table 3 we examine Safe Haven in Crisis Hypothesis. As shown in regressions (1) and (4), the existence of an explicit $D I$ is important for foreign depositors both in stable times and in times of crises. This indicates that when the depositor's home country is undergoing a systemic banking crisis, depositors still trust the foreign DI systems. Furthermore, the power of the DI agency and the actions taken to mitigate DI-induced moral are found to be more important during times of crises. Economically regressions (5) and (6) indicate that one unit stronger DI power and DI moral hazard mitigation is associated with $8.3 \%$ and $11.6 \%$ more cross-border deposits during crisis times compared to only $6.2 \%$ and $7.3 \%$ during stable times, respectively. These results support our Safe Haven in Crisis Hypothesis and indicate that depositors value safe havens more when their home countries are undergoing a systemic banking crisis.

When it comes to specific DI design features in bank countries during stable and crisis times, Panel B of Table 3 shows several remarkable findings. Firstly, the coverage ratio as a measure for the degree of depositor protection in the bank country, is only important when depositors experience a crisis at home. Secondly, the existence of formal coinsurance only matters during stable times, maybe due to the fact that under most DI schemes the depositors' self-burden is low, typically ranging from $10 \%$ to $25 \%$. During crises, depositors care more about whether their covered portion of deposits can be claimed or not, rather than about the relatively smaller self-burden portion.

average depositor can relocate funds quickly in response to changes in the DI scheme. However, the lower significance may also be due to the fact that our filling methodology already ensured that the DI variables are pre-determined and thus already include an implicit lag. Thus in the following sections, we only report the results without lagged DI variables. 
Thirdly, during a systemic banking crisis, depositors pay more attention to historical records of the DI systems as the three- to four-fold increase in the additional compensation coefficient between stable and crisis times shows. When it comes to the overall coverage of the banking system, we can find that the percentage of insured funding is equally important in stable as crises times while a higher uninsured ratio is generally irrelevant. This indicates that depositors care more about what is insured than what is not. Summarizing the results from Panel A and B shows that the importance of a safe haven for cross-border depositors is especially important during crisis times when the existence of an explicit DI, high DI power, strong DI moral hazard mitigation and a high coverage ratio are highly relevant to cross-border depositors.

\section{[Insert Table 3 about here]}

Using model (4) to test our Regulatory Arbitrage in Crisis Hypothesis, Table 4 reports the results during stable and crisis times for the differences in DI between bank and depositor countries. Panel A reveals that depositors are more willing to chase "better" explicit DI in stable times. Even more distinctly, $D I$ power only matters during stable times. This result stands in contrast to the results for Safe Haven in Crisis Hypothesis in Table 3 where effects become stronger rather than weaker during a crisis. One possible explanation could be that depositors consider regulatory arbitrage during stable times, but when they are hit by a crisis, they care less about the arbitrage opportunities and only care whether their deposits are relatively safe, that is, whether their deposits are deposited in countries with better explicit and more powerful DI. Panel B investigates the role of specific DI design features. Again, regulatory arbitrage turns out to be not relevant during crises. Overall, Table 4 therefore suggests that regulatory arbitrage behavior decreases or even disappears in times of crises and depositors only move across borders when they are not protected by an explicit or powerful DI scheme at home.

The evidence provided here indicates that safe havens are becoming more important during crisis times while regulatory arbitrage only remains relevant for depositors from countries without an explicit DI. On might say, that depositors search for the best protection in time of crisis and thus relocate deposits to safe havens. Only during stable times are depositors willing to consider regulatory arbitrage.

[Insert Table 4 about here] 


\subsection{The Role of Emergency Actions during Global Financial Crisis}

Our analysis so far suggests that during a banking crisis in the home country, safe havens become important to depositors. However, during the 2008/09 financial crisis safe havens were in short supply as bank countries which for most of the time of our analysis had not experienced a banking crisis are now subject to a crisis as well. As a consequence, many bank countries took emergency actions by implementing explicit DI schemes or enhancing government guarantees. To examine the impact of such emergency actions on cross-border deposits, we employ a difference in difference analysis as outlined in model (5) and thereby test our Emergency Actions Hypothesis. Results are shown in Table 5. It is important to note that we do not only rely on the full sample of country-pairs involving all bank countries, but also conduct the difference in difference analysis with a subsample containing only those country-pairs for which the bank countries have experienced the 2008/09 crisis. By doing this, we can further narrow down our control groups, thus making our results more precise, i.e. countries that have undergone the 2008/09 crisis have similar characteristics and this similarity is higher within this subgroup than compared to countries that were not exposed to the 2008/09 crisis. We start with regression (1) where we examine the impact of an explicit DI introduction and show that this emergency measure significantly increases cross-border deposits. Similarly regressions (2) to (4) show that cross-border deposits increase when government guarantees, whether limited or unlimited, are introduced. Regressions (1) to (4) are based on our full sample of country-pairs based on all 22 bank countries. ${ }^{18}$ Regressions (5) to (7) are based on the subsample of country-pairs for which the bank countries have experienced the 2008/09 crisis but we find almost the identical results as in regressions (2) to (4), indicating that our control groups are unbiased. In addition, besides the full time period of 1998-2011, we also check the treatment effect with a narrower time window from 2006 to 2009 which captures the 4 years surrounding the introduction of emergency actions in 2008. Results are shown in regressions (8) to (14). This shorter period mitigate the time trend concern in the sense that the early years of the sample period (19982005) could be - for reasons unrelated to the crisis - substantially different than the more recent years and confirms our previous results. In sum, the emergency actions appear to be very successful in terms of providing the safe havens that depositors were looking for during a global financial crisis.

\section{[Insert Table 5 about here]}

\footnotetext{
${ }^{18}$ We have no information on emergency actions for Macao SAR and Panama.
} 


\title{
5. Conclusions
}

Our results indicate that the existence of an explicit DI, as well as other DI design features, affect cross-border depositing and thus the geography of global banking. The existence of an explicit $\mathrm{DI}$ is attractive to foreign depositors in the sense that it provides a higher level of deposit safety. But the design of the DI plays an important role, too. Eisenbeis \& Kaufman (2015) argue that an effective DI system consist of a credible guarantee, effective monitoring by supervisors, and an efficient resolution mechanism. Our results show that the DI power and moral hazard mitigation proxies which encompass credibility and effective monitoring matter also for cross-border depositing. Our findings regarding specific DI design features further underline the importance of credibility as depositors identify safe havens as those banking markets with DI schemes that provide high coverage, additional compensation and low coinsurance. We further demonstrate that the relationships between DI systems and cross-border deposits vary in stable times and in times of systemic banking crisis in depositor countries. In crises times depositors have more incentives to chase a safe haven rather than to engage in regulatory arbitrage. When it comes to a global finance crisis it is the emergency actions of bank country governments, which supply and maintain these safe havens, that matter and can lead substantial relocations of cross-border deposits. As such, these actions do not only rescue the banks and domestic depositors of the countries taking these (credible) emergency actions. They also have measurable and sizeable effects on other countries in a financially interdependent world, which may call for coordinated emergency actions which take possible spillovers across countries into account. However, even in tranquil times, our results show that the design of an effective DI must take the DI's impact on cross-border activities of depositors into account. Our findings add therefore also to the debate on the design of macroprudential instruments in globalized financial markets. This discussion, currently focused on bank lending, questions their effectiveness when banks and borrowers are able to circumvent these measures via regulatory arbitrage and calls for coordination among national regulators (Houston, Lin \& Ma, 2012; Ongena, Popov \& Udell, 2013; Reinhardt \& Sowerbutts, 2015). Likewise, our findings, documenting a novel pattern of save haven and regulatory arbitrage driven behavior by depositors, stresses the need for a coordinated regulatory strategy with respect to deposit insurance schemes.

\section{Appendix}

\author{
[Insert Tables A1 to A5 here]
}




\section{References}

Anderson, J. E., \& Van Wincoop, E. (2003). Gravity with gravitas: A solution to the border puzzle. American Economic Review, 93(1), 170-192.

Alworth, J. S., \& Andresen, S. (1992). The determinants of cross border non-bank deposits and the competitiveness of financial market centres. Money Affairs, 5(2), 105-33.

Aviat, A., \& Coeurdacier, N. (2007). The geography of trade in goods and asset holdings. Journal of International Economics, 71(1), 22-51.

Baldwin, R., \& Taglioni, D. (2006). Gravity for dummies and dummies for gravity equations (No. w12516). National Bureau of Economic Research.

Baltagi, B. H., Egger, P., \& Pfaffermayr, M. (2003). A generalized design for bilateral trade flow models. Economics Letters, 80(3), 391-397.

Barth, J. R., Caprio, G., \& Levine, R. (2001). The regulation and supervision of banks around the world: A new database (Vol. 2588). World Bank Publications.

Barth, J. R., Caprio, G., \& Levine, R. (2004). Bank regulation and supervision: What works best? Journal of Financial Intermediation, 13(2), 205-248.

Barth, J. R., Caprio Jr, G., \& Levine, R. (2013). Bank regulation and supervision in 180 countries from 1999 to 2011. Journal of Financial Economic Policy, 5(2), 111-219.

Baxter, M., \& Kouparitsas, M. A. (2006). What determines bilateral trade flows? (No. w12188). National Bureau of Economic Research.

Bekaert, G., Harvey, C. R., Lundblad, C. T., \& Siegel, S. (2013). The European Union, the Euro, and equity market integration. Journal of Financial Economics, 109(3), 583-603.

Berger, A. N. (1991). Market discipline in banking (No. 328). Federal Reserve Bank of Chicago Proceedings.

Bernet, B., \& Walter, S. (2009). Design, structure and implementation of a modern deposit insurance scheme (Vol. 5). SUERF.

Buch, C. M. (2005). Distance and international banking. Review of International Economics, 13(4), 787-804.

Buch, C. M., \& Lipponer, A. (2007). FDI versus exports: Evidence from German banks. Journal of banking \& Finance, 31(3), 805-826.

Cihak, M., Demirgüç-Kunt, A., Martínez Pería, M. S., \& Mohseni-Cheraghlou, A. (2012). Bank regulation and supervision around the world: A crisis update (No. 6286). World Bank Policy Research Working Paper.

Coeurdacier, N., \& Martin, P. (2009). The geography of asset trade and the euro: Insiders and outsiders. Journal of the Japanese and International Economies, 23(2), 90-113.

Dale, R., Bruni, F., \& de Boissieu, C. (2000). Strengthening financial infrastructure: Deposit insurance and lending of last resort. SUERF-The European Money and Finance Forum.

Demirgüç-Kunt, A., \& Detragiache, E. (1997). The determinants of banking crises: Evidence from developing and developed countries (Vol. 106). World Bank Publications.

Demirgüç-Kunt, A., \& Detragiache, E. (2002). Does deposit insurance increase banking system stability? An empirical investigation. Journal of Monetary Economics, 49(7), 1373-1406.

Demirgüç-Kunt, A., Kane, E. J., \& Laeven, L. (2014). Deposit insurance database (No. w20278). National Bureau of Economic Research.

Demirgüç-Kunt, A., Karacaovali, B., \& Laeven, L. (2005). Deposit insurance around the world: A comprehensive database (No. 3628). World Bank Policy Research Working Paper.

Demirgüç-Kunt, A., \& Sobaci, T. (2001). A new development database: Deposit insurance around the world. World Bank Economic Review, 15(3), 481-490.

Diamond, D. W. (1983). Bank runs, deposit insurance, and liquidity. Journal of Political Economy, 91(3), 401-419.

Diamond, D. W., \& Dybvig, P. H. (1986). Banking theory, deposit insurance, and bank regulation. Journal of Business, 59(1), 55-68. 
Ding, W., Domac, I., \& Ferri, G. (1998). Is there a credit crunch in East Asia? (No. 1959). World Bank Policy Research Working Paper.

Eisenbeis, R. A., \& Kaufman, G. G. (2007). Cross-border banking: Challenges for deposit insurance and financial stability in the European Union (No. 2006-15a). Federal Reserve Bank of Atlanta.

Eisenbeis, R. A., \& Kaufman, G. G. (2008). Cross-border banking and financial stability in the EU. Journal of Financial Stability, 4(3), 168-204.

Eisenbeis, R. A., \& Kaufman, G. G. (2015). Deposit insurance issues in the post-2008 crisis world. In Berger, A.N., Molyneux P., \& Wilson, J.O.S. (Eds.), The Oxford handbook of banking (pp. 527549). Oxford, England: Oxford University Press.

Garcia, G. G. H. (1999). Deposit insurance: A survey of actual and best practices. New York, NY: International Monetary Fund.

Grilli, V. (1989). Europe 1992: Issues and prospects for the financial markets. Economic Policy, 4(9), 387-421.

Helpman, E., \& Krugman, P. R. (1985). Market structure and foreign trade: Increasing returns, imperfect competition, and the international economy. Cambridge, MA: MIT Press.

Heuchemer, S., Kleimeier, S., \& Sander, H. (2009). The determinants of cross-border lending in the Euro zone. Comparative Economic Studies, 51(4), 467-499.

Hoelscher, D. S., Taylor, M., \& Klueh, U. H. (2006). The design and implementation of deposit insurance systems (No. 251). International Monetary Fund Publications.

Huizinga, H., \& Nicodème, G. (2004). Are international deposits tax-driven? Journal of Public Economics, 88(6), 1093-1118.

Huizinga, H., \& Nicodème, G. (2006). Deposit insurance and international bank liabilities. Journal of Banking \& Finance, 30(3), 965-987.

Houston, J. F., Lin, C., \& Ma, Y. (2012). Regulatory arbitrage and international bank flows. Journal of Finance, 67(5), 1845-1895.

Ilzetzki, E., Reinhart, C., \& Rogoff, K. (2008). The country chronologies and background material to exchange rate arrangements in the 21st century: Which anchor will hold? mimeo, University of Maryland.

Kleimeier, S., Sander, H., \& Heuchemer, S. (2013). Financial crises and cross-border banking: New evidence. Journal of International Money and Finance, 32, 884-915.

Kleimeier, S., Sander, H., \& Heuchemer, S. (2014). The resurgence of cultural borders in international finance during the financial crisis: Evidence from Eurozone cross-border depositing (No. 013). Maastricht University, Graduate School of Business and Economics (GSBE).

Krugman, P. (1980). Scale economies, product differentiation, and the pattern of trade. American Economic Review, 70(5), 950-959.

Laeven, L., \& Beck, T. (2006). Resolution of failed banks by deposit insurers: Cross-country evidence (No. 3920). World Bank Policy Research Working Paper.

Laeven, L., \& Valencia, F. (2008). Systemic banking crises: A new database (No. 08/224). International Monetary Fund.

Laeven, L., \& Valencia, F. (2010). Resolution of banking crises: The good, the bad, and the ugly (No. 10/146). International Monetary Fund.

Laeven, L., \& Valencia, F. (2012). Systemic banking crises database: An update (No. 12/163). International Monetary Fund.

Lane, P. R., \& Milesi-Ferretti, G. M. (2008). International investment patterns. Review of Economics and Statistics, 90(3), 538-549.

Lane, P. R., \& Sarisoy, S. (2000). Does deposit insurance stimulate capital inflows? Economics Letters, 69(2), 193-200.

Martin, P., \& Rey, H. (2004). Financial super-markets: Size matters for asset trade. Journal of International Economics, 64(2), 335-361.

Martinez Peria, M., \& Schmukler, S. (2001). Do depositors punish banks for bad behavior? Market discipline, deposit insurance, and banking crisis. Journal of Finance, 56(3), 1029-1051. 
Merton, R. C., \& Thakor, R. T. (2015). Customers and investors: A framework for understanding financial institutions (No. w21258). National Bureau of Economic Research.

Okawa, Y., \& Van Wincoop, E. (2012). Gravity in international finance. Journal of International Economics, 87(2), 205-215.

Ongena, S., Popov, A., \& Udell, G. F. (2013). "When the cat's away the mice will play": does regulation at home affect bank risk-taking abroad?. Journal of Financial Economics, 108(3), 727-750.

Park, S., \& Peristiani, S. (1998). Market discipline by thrift depositors. Journal of Money, Credit and Banking, 30(3), 347-364.

Portes, R., \& Rey, H. (2005). The determinants of cross border equity flows. Journal of International Economics, 65(2), 269-296.

Pöyhönen, P. (1963). A tentative model for the volume of trade between countries. Weltwirtschaftliches Archiv, 90(1), 93-99.

Reinhardt, D., \& Sowerbutts, R. (2015), "Regulatory arbitrage in action: evidence from banking flows and macroprudential policy (No. 546). Bank of England Staff Working Paper.

Rochet, J.-C. (2004). Market discipline in banking: Where do we stand. In C Borio, WC Hunter, G Kaufman, K Tsatsaronis (Eds), Market discipline across countries and industries (pp. 55-68). Cambridge, MA: MIT Press.

Rose, A. K. (2005). Does the WTO make trade more stable? Open Economies Review, 16(1), 7-22.

Rossi, M. (1999). Financial fragility and economic performance in developing economies: Do capital controls, prudential regulation and supervision matter? (No. 99/66). International Monetary Fund.

Sander, H., Kleimeier, S., \& Heuchemer, S. (2013). E(M)U effects in global cross-border banking. Economics Letters, 118(1), 91-93.

Tinbergen, J. (1962). Shaping the world economy; suggestions for an international economic policy. In Jan Tinbergen (Ed.), Books (Jan Tinbergen). New York, NY: Twentieth Century Fund. 
Table 1. Testing the Safe Haven Hypothesis

Panel A: Main features of the deposit insurance scheme

Explicit DI

DI power

DI moral hazard mitigation

Size

Credit

Trade

Globalisation

FTA

Currency union

Bank country fixed effect Depositor country fixed effect Country-pair fixed effect Year fixed effect

Adjusted R-squared

Observations
(2) $1.73^{* * *}$ (33.52)

$0.06^{* * *}$

(4.78)

$\begin{array}{rr}0.31^{* * *} & 0.01^{*} \\ (33.02) & (0.96)\end{array}$

(33.02)

(0.96)

$0.05^{* *}$

(2.23)

0.01

(0.91)

(3)

(4)

$1.49^{* * *}$

(28.44)

(5)

(6)

$(28.44)$

$0.06^{* * *}$

(4.51)

$0.07^{* * *}$

$0.01 \quad 0.01$

(0.43) $\quad(0.96)$

$1.56^{* * *} \quad 0.07^{* *}-0.15^{* * *}$

(42.55) (2.27) (-6.13)

$0.05^{* * *} \quad 0.03^{* *} \quad 0.03^{* *}$

$\begin{array}{lll}(10.21) & (2.30) \quad(2.38)\end{array}$

$-0.02 * * * \quad-0.01 * * * \quad-0.01 * * *$

$\begin{array}{lll}(-10.01) & (-3.64) \quad(-3.53)\end{array}$

$0.59^{* * *} \quad 0.22^{* * *} \quad 0.13^{* * *}$

(9.34) (4.83) (3.07)

$0.52^{* * *} \quad 0.33^{* * *} \quad 0.41^{* * *}$

(5.97) (4.05) (5.53)

\begin{tabular}{rrrrrr} 
No & Yes & Yes & No & Yes & Yes \\
Yes & Yes & Yes & Yes & Yes & Yes \\
No & Yes & Yes & No & Yes & Yes \\
Yes & Yes & Yes & Yes & Yes & Yes \\
& & & & & \\
0.449 & 0.944 & 0.945 & 0.500 & 0.945 & 0.945 \\
23,487 & 15,923 & 17,809 & 23,487 & 15,923 & 17,809 \\
\hline
\end{tabular}


Table 1. Testing the Safe Haven Hypothesis

Panel B: Specific features of the deposit insurance scheme

\begin{tabular}{|c|c|c|c|c|c|c|c|c|c|c|c|c|c|c|c|c|c|c|}
\hline & (1) & (2) & (3) & (4) & (5) & (6) & (7) & (8) & (9) & (10) & (11) & (12) & (13) & (14) & (15) & (16) & (17) & (18) \\
\hline Coverage ratio & $\begin{array}{r}0.06^{* *} \\
(2.05)\end{array}$ & & & & & & & & & $\begin{array}{r}0.05 \\
(1.61)\end{array}$ & & & & & & & & \\
\hline Limit per person & & $\begin{array}{r}-0.02 \\
(-0.65)\end{array}$ & & & & & & & & & $\begin{array}{r}-0.03 \\
(-1.09)\end{array}$ & & & & & & & \\
\hline Coinsurance & & & $\begin{array}{l}-0.05^{*} \\
(-1.93)\end{array}$ & & & & & & & & & $\begin{array}{r}-0.06^{* *} \\
(-2.18)\end{array}$ & & & & & & \\
\hline Foreign currency coverage & & & & $\begin{array}{r}0.02 \\
(0.74)\end{array}$ & & & & & & & & & $\begin{array}{r}0.01 \\
(0.40)\end{array}$ & & & & & \\
\hline Additional compensation & & & & & $\begin{array}{r}0.05^{* * *} \\
(2.96)\end{array}$ & & & & & & & & & $\begin{array}{r}0.08^{* * *} \\
(4.48)\end{array}$ & & & & \\
\hline Uninsured ratio & & & & & & $\begin{array}{r}-0.06 \\
(-1.60)\end{array}$ & & & & & & & & & $\begin{array}{r}-0.04 \\
(-1.13)\end{array}$ & & & \\
\hline Insured funding & & & & & & & $\begin{array}{r}0.01^{* * *} \\
(3.66)\end{array}$ & & & & & & & & & $\begin{array}{r}0.01^{* * *} \\
(2.90)\end{array}$ & & \\
\hline Funding source index & & & & & & & & $\begin{array}{r}-0.04^{* *} \\
(-2.03)\end{array}$ & & & & & & & & & $\begin{array}{r}-0.02 \\
(-1.28)\end{array}$ & \\
\hline Compulsory participation & & & & & & & & & $\begin{array}{r}0.01 \\
(0.31)\end{array}$ & & & & & & & & & $\begin{array}{r}0.01 \\
(0.13)\end{array}$ \\
\hline Size & $\begin{array}{r}0.09 * * \\
(2.54)\end{array}$ & $\begin{array}{r}0.01 \\
(1.23)\end{array}$ & $\begin{array}{r}0.02 \\
(1.52)\end{array}$ & $\begin{array}{l}0.02^{*} \\
(1.72)\end{array}$ & $\begin{array}{r}0.02 * * \\
(2.00)\end{array}$ & $\begin{array}{r}0.04 * * \\
(2.44)\end{array}$ & $\begin{array}{r}0.01 \\
(0.60)\end{array}$ & $\begin{array}{r}0.00 \\
(0.42)\end{array}$ & $\begin{array}{r}0.03 * * \\
(2.01)\end{array}$ & $\begin{array}{r}0.08^{* *} \\
(2.41)\end{array}$ & $\begin{array}{r}0.01 \\
(1.25)\end{array}$ & $\begin{array}{r}0.02 \\
(1.21)\end{array}$ & $\begin{array}{r}0.02 \\
(1.42)\end{array}$ & $\begin{array}{r}0.02^{* *} \\
(2.12)\end{array}$ & $\begin{array}{l}0.03^{*} \\
(1.78)\end{array}$ & $\begin{array}{r}0.01 \\
(0.47)\end{array}$ & $\begin{array}{r}0.01 \\
(0.53)\end{array}$ & $\begin{array}{l}0.02 * \\
(1.71)\end{array}$ \\
\hline Credit & & & & & & & & & & $\begin{array}{r}-0.28^{* * *} \\
(-10.29)\end{array}$ & $\begin{array}{r}-0.10^{* * *} \\
(-4.79)\end{array}$ & $\begin{array}{r}0.04 \\
(1.18)\end{array}$ & $\begin{array}{r}-0.00 \\
(-0.03)\end{array}$ & $\begin{array}{r}-0.14^{* * *} \\
(-6.28)\end{array}$ & $\begin{array}{r}0.04 \\
(1.18)\end{array}$ & $\begin{array}{r}-0.12 * * \\
(-1.98)\end{array}$ & $\begin{array}{r}-0.11^{* * *} \\
(-5.22)\end{array}$ & $\begin{array}{r}-0.01 \\
(-0.34)\end{array}$ \\
\hline Trade & & & & & & & & & & $\begin{array}{l}0.01^{*} \\
(1.83)\end{array}$ & $\begin{array}{r}0.02 * * * \\
(4.03)\end{array}$ & $\begin{array}{r}0.02 \\
(1.44)\end{array}$ & $\begin{array}{r}0.02 \\
(1.41)\end{array}$ & $\begin{array}{r}0.02^{* * *} \\
(3.41)\end{array}$ & $\begin{array}{r}0.05^{* * *} \\
(3.69)\end{array}$ & $\begin{array}{r}0.02 \\
(0.73)\end{array}$ & $\begin{array}{r}0.02 * * * \\
(3.74)\end{array}$ & $\begin{array}{r}0.02 \\
(1.33)\end{array}$ \\
\hline Globalisation & & & & & & & & & & $\begin{array}{r}0.00 \\
(0.79)\end{array}$ & $\begin{array}{r}-0.01^{* * *} \\
(-3.98)\end{array}$ & $\begin{array}{r}-0.01 * * * \\
(-3.15)\end{array}$ & $\begin{array}{r}-0.01 * * * \\
(-3.09)\end{array}$ & $\begin{array}{r}-0.01^{* * *} \\
(-2.58)\end{array}$ & $\begin{array}{r}-0.00 \\
(-0.62)\end{array}$ & $\begin{array}{l}-0.01 * \\
(-1.96)\end{array}$ & $\begin{array}{r}-0.01 * * \\
(-2.57)\end{array}$ & $\begin{array}{r}-0.01^{* * *} \\
(-3.56)\end{array}$ \\
\hline FTA & & & & & & & & & & $\begin{array}{r}-0.08 \\
(-0.16)\end{array}$ & $\begin{array}{r}0.16^{* * *} \\
(4.24)\end{array}$ & $\begin{array}{r}0.14^{* * *} \\
(2.86)\end{array}$ & $\begin{array}{r}0.16^{* * *} \\
(3.41)\end{array}$ & $\begin{array}{r}0.23^{* * *} \\
(5.06)\end{array}$ & $\begin{array}{r}0.23 * * * \\
(3.58)\end{array}$ & $\begin{array}{r}0.09 \\
(1.10)\end{array}$ & $\begin{array}{r}0.14^{* * *} \\
(3.57)\end{array}$ & $\begin{array}{r}0.16^{* * *} \\
(3.49)\end{array}$ \\
\hline Currency union & & & & & & & & & & $\begin{array}{r}0.34^{* * *} \\
(6.47)\end{array}$ & $\begin{array}{r}0.33^{* * *} \\
(5.38)\end{array}$ & $\begin{array}{r}-0.24 \\
(-1.13)\end{array}$ & $\begin{array}{r}-0.16 \\
(-0.75)\end{array}$ & $\begin{array}{r}0.35^{* * *} \\
(5.25)\end{array}$ & $\begin{array}{r}0.22 * * * \\
(2.80)\end{array}$ & $\begin{array}{r}0.09 \\
(0.27)\end{array}$ & $\begin{array}{r}0.35^{* * *} \\
(5.58)\end{array}$ & $\begin{array}{r}-0.16 \\
(-0.76)\end{array}$ \\
\hline Bank country fixed effect & Yes & Yes & Yes & Yes & Yes & Yes & Yes & Yes & Yes & Yes & Yes & Yes & Yes & Yes & Yes & Yes & Yes & Yes \\
\hline Depositor country fixed effect & Yes & Yes & Yes & Yes & Yes & Yes & Yes & Yes & Yes & Yes & Yes & Yes & Yes & Yes & Yes & Yes & Yes & Yes \\
\hline Country-pair fixed effect & Yes & Yes & Yes & Yes & Yes & Yes & Yes & Yes & Yes & Yes & Yes & Yes & Yes & Yes & Yes & Yes & Yes & Yes \\
\hline Year fixed effect & Yes & Yes & Yes & Yes & Yes & Yes & Yes & Yes & Yes & Yes & Yes & Yes & Yes & Yes & Yes & Yes & Yes & Yes \\
\hline Adjusted R-squared & 0.966 & 0.947 & 0.955 & 0.955 & 0.948 & 0.958 & 0.938 & 0.943 & 0.953 & 0.967 & 0.947 & 0.955 & 0.955 & 0.948 & 0.958 & 0.938 & 0.943 & 0.953 \\
\hline Observations & 12,980 & 21,575 & 12,591 & 13,207 & 16,465 & 7,951 & 8,417 & 21,491 & 13,097 & 12,980 & 21,575 & 12,591 & 13,207 & 16,465 & 7,951 & 8,417 & 21,491 & 13,097 \\
\hline
\end{tabular}

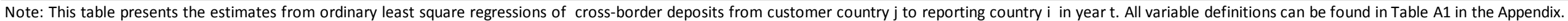

The coefficients are reported in the top row, $\mathrm{t}$-values are reported below in brackets. $*, * *, * * *$ represent statistical significance at the $10 \%, 5 \%$ and $1 \%$ level, respectively. 
Table 2. Testing the Regulatory Arbitrage Hypothesis

Panel A: Main features of the deposit insurance scheme

Explicit DI

$1.30 * * *$

(2)

(3)

(4)

(5)

(6)

DI power

(25.56)

$0.04 * * *$

(20.14)

(2.68)

$0.04^{* *}$
$(2.43)$

DI moral hazard mitigation

0.03

(1.41)

Size

$0.37 * * *$

0.07

$(1.41)$
$0.25^{* * *}$

(33.55)

(1.14)

(4.03)

Credit

Trade

Globalisation

FTA

Currency union

Bank country fixed effect

Depositor country fixed effect

Country-pair fixed effect

Year fixed effect

Adjusted R-squared

Observations

$\begin{array}{rr}\text { No } & \text { Yes } \\ \text { Yes } & \text { Yes } \\ \text { No } & \text { Yes } \\ \text { Yes } & \text { Yes } \\ & \\ 0.443 & 0.949 \\ 18,525 & 7,076\end{array}$

Yes

Yes

Yes

0.03

$0.36^{* * *} \quad 0.04 \quad 0.29 * *$

$\begin{array}{ll}0.04 & 0.29 * * *\end{array}$

$\begin{array}{lll}(29.42) & (0.58) \quad(4.29)\end{array}$

$\begin{array}{lll}1.56^{* * *} & 0.06 & 0.00\end{array}$

$(37.21) \quad(1.40) \quad(0.05)$

$0.05 * * * \quad 0.02 \quad-0.03$

(8.84) (0.72) (-1.32)

$-0.01^{* * *} \quad-0.01^{* * *} \quad-0.02^{* * *}$

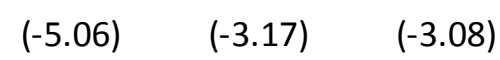

$0.61^{* * *} \quad 0.15^{* * *} \quad 0.02$

(9.04) (2.99) (0.41)

$0.47 * * * \quad 0.09 \quad 0.23 *$

$\begin{array}{lll}(5.02) & (0.86) \quad(1.94)\end{array}$

18,525

7,076

0.952

6,808

\begin{tabular}{rrr} 
No & Yes & Yes \\
Yes & Yes & Yes \\
No & Yes & Yes \\
Yes & Yes & Yes \\
& & \\
0.498 & 0.949 & 0.952 \\
18,525 & 7,076 & 6,808 \\
\hline \multicolumn{3}{c}{ (continued) }
\end{tabular}


Table 2. Testing the Regulatory Arbitrage Hypothesis

Panel B: Specific features of the deposit insurance schem

\begin{tabular}{|c|c|c|c|c|c|c|c|c|c|c|c|c|c|c|c|c|c|c|}
\hline 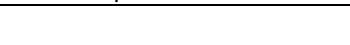 & (1) & (2) & (3) & (4) & (5) & (6) & (7) & (8) & (9) & (10) & (11) & (12) & (13) & (14) & (15) & (16) & (17) & (18) \\
\hline \multirow[t]{2}{*}{ Coverage ratio } & -0.00 & & & & & & & & & -0.00 & & & & & & & & \\
\hline & $(-0.12)$ & & & & & & & & & $(-0.21)$ & & & & & & & & \\
\hline \multirow[t]{2}{*}{ Limit per person } & & -0.04 & & & & & & & & & $-0.05^{*}$ & & & & & & & \\
\hline & & $(-1.46)$ & & & & & & & & & $(-1.79)$ & & & & & & & \\
\hline \multirow[t]{2}{*}{ Coinsurance } & & & -0.03 & & & & & & & & & -0.01 & & & & & & \\
\hline & & & $(-0.82)$ & & & & & & & & & $(-0.45)$ & & & & & & \\
\hline \multirow[t]{2}{*}{ Foreign currency coverage } & & & & -0.02 & & & & & & & & & -0.04 & & & & & \\
\hline & & & & $(-0.66)$ & & & & & & & & & $(-1.00)$ & & & & & \\
\hline \multirow[t]{2}{*}{ Additional compensation } & & & & & $0.06^{* * *}$ & & & & & & & & & $0.07^{* * *}$ & & & & \\
\hline & & & & & (2.58) & & & & & & & & & $(2.90)$ & & & & \\
\hline \multirow[t]{2}{*}{ Uninsured ratio } & & & & & & -0.07 & & & & & & & & & -0.07 & & & \\
\hline & & & & & & $(-1.17)$ & & & & & & & & & $(-1.17)$ & & & \\
\hline \multirow[t]{2}{*}{ Insured funding } & & & & & & & $0.00^{*}$ & & & & & & & & & 0.00 & & \\
\hline & & & & & & & $(1.95)$ & & & & & & & & & (1.59) & & \\
\hline \multirow[t]{2}{*}{ Funding source index } & & & & & & & & $-0.07^{* * *}$ & & & & & & & & & $-0.06^{* * *}$ & \\
\hline & & & & & & & & $(-3.83)$ & & & & & & & & & $(-3.55)$ & \\
\hline \multirow[t]{2}{*}{ Compulsory participation } & & & & & & & & & 0.04 & & & & & & & & & 0.03 \\
\hline & & & & & & & & & $(0.81)$ & & & & & & & & & $(0.61)$ \\
\hline \multirow[t]{2}{*}{ Size } & $0.16^{* * *}$ & $0.24^{* * *}$ & $0.25^{* * *}$ & $0.23^{* * *}$ & $0.22 * * *$ & $0.55^{* * *}$ & 0.01 & $0.21^{* * *}$ & $0.30^{* * *}$ & $0.16^{* * *}$ & $0.29 * * *$ & $0.22^{* *}$ & $0.20^{* * *}$ & $0.25 * * *$ & $0.58^{* * *}$ & 0.04 & $0.25^{* * *}$ & $0.30^{* * *}$ \\
\hline & (2.63) & (5.48) & (3.02) & (3.22) & (4.32) & $(5.26)$ & $(0.12)$ & $(4.60)$ & (4.46) & $(2.73)$ & (6.23) & $(2.57)$ & (2.69) & $(4.70)$ & $(5.07)$ & $(0.40)$ & (5.35) & (4.24) \\
\hline \multirow[t]{2}{*}{ Credit } & & & & & & & & & & $-0.29 * * *$ & $-0.08 * * *$ & -0.02 & -0.04 & $-0.10 * *$ & -0.02 & $-0.22 * * *$ & $-0.10 * * *$ & -0.06 \\
\hline & & & & & & & & & & $(-6.84)$ & $(-2.76)$ & $(-0.39)$ & $(-0.89)$ & $(-2.51)$ & $(-0.37)$ & $(-3.21)$ & $(-3.22)$ & $(-1.36)$ \\
\hline \multirow[t]{2}{*}{ Trade } & & & & & & & & & & $0.01^{*}$ & $0.02^{* *}$ & 0.02 & 0.03 & 0.01 & -0.02 & -0.01 & $0.01 *$ & 0.01 \\
\hline & & & & & & & & & & $(1.84)$ & (2.19) & $(0.73)$ & (1.11) & $(1.22)$ & $(-0.56)$ & $(-0.26)$ & (1.75) & $(0.25)$ \\
\hline \multirow[t]{2}{*}{ Globalisation } & & & & & & & & & & -0.01 & $-0.02^{* * *}$ & $-0.02^{* * *}$ & $-0.02^{* * *}$ & $-0.01 * * *$ & -0.01 & -0.00 & $-0.01^{* * *}$ & $-0.02^{* * *}$ \\
\hline & & & & & & & & & & $(-1.38)$ & $(-5.02)$ & $(-3.42)$ & $(-3.49)$ & $(-2.79)$ & $(-1.02)$ & $(-0.21)$ & $(-3.31)$ & $(-4.38)$ \\
\hline \multirow[t]{2}{*}{ FTA } & & & & & & & & & & -0.07 & 0.05 & $0.11^{*}$ & $0.13^{* *}$ & $0.12^{* *}$ & 0.01 & 0.04 & 0.01 & $0.15^{* * *}$ \\
\hline & & & & & & & & & & $(-0.14)$ & $(1.03)$ & (1.86) & $(2.43)$ & $(2.29)$ & $(0.07)$ & $(0.39)$ & $(0.30)$ & (2.93) \\
\hline \multirow[t]{2}{*}{ Currency union } & & & & & & & & & & $0.30 * * *$ & $0.30^{* * *}$ & -0.30 & -0.20 & $0.48^{* * *}$ & -0.00 & 0.01 & $0.32^{* * *}$ & -0.21 \\
\hline & & & & & & & & & & (5.01) & (4.28) & $(-1.29)$ & $(-0.90)$ & $(5.59)$ & $(-0.00)$ & $(0.04)$ & (4.48) & $(-0.94)$ \\
\hline Bank country fixed effect & Yes & Yes & Yes & Yes & Yes & Yes & Yes & Yes & Yes & Yes & Yes & Yes & Yes & Yes & Yes & Yes & Yes & Yes \\
\hline Depositor country fixed effect & Yes & Yes & Yes & Yes & Yes & Yes & Yes & Yes & Yes & Yes & Yes & Yes & Yes & Yes & Yes & Yes & Yes & Yes \\
\hline Country-pair fixed effect & Yes & Yes & Yes & Yes & Yes & Yes & Yes & Yes & Yes & Yes & Yes & Yes & Yes & Yes & Yes & Yes & Yes & Yes \\
\hline Year fixed effect & Yes & Yes & Yes & Yes & Yes & Yes & Yes & Yes & Yes & Yes & Yes & Yes & Yes & Yes & Yes & Yes & Yes & Yes \\
\hline Adjusted R-squared & 0.970 & 0.947 & 0.951 & 0.952 & 0.956 & 0.972 & 0.943 & 0.945 & 0.951 & 0.971 & 0.947 & 0.951 & 0.952 & 0.957 & 0.972 & 0.943 & 0.945 & 0.952 \\
\hline Observations & 5,461 & 9,902 & 5,906 & 6,638 & 6,443 & 2,108 & 4,299 & 9,900 & 6,893 & 5,461 & 9,902 & 5,906 & 6,638 & 6,443 & 2,108 & 4,299 & 9,900 & 6,893 \\
\hline
\end{tabular}

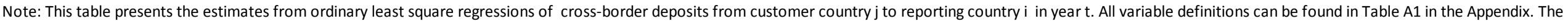
coefficients are reported in the top row, t-values are reported below in brackets. ${ }^{*}, * *, * *$ represent statistical significance at the $10 \%, 5 \%$ and $1 \%$ level, respectively. 
Table 3. Testing the Safe Haven in Crisis Hypothesis

Panel A: Main features of the deposit insurance scheme

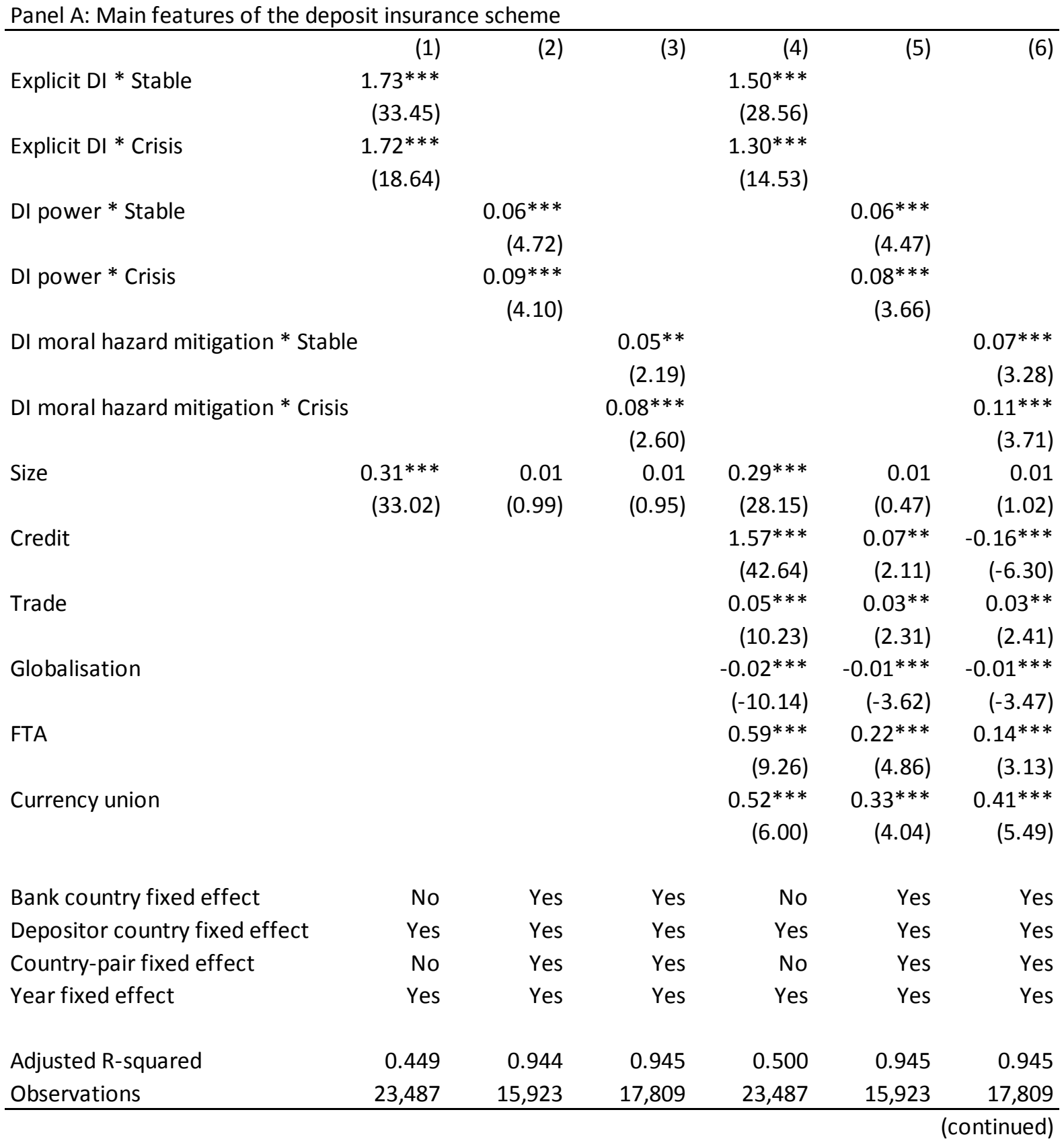


Table 3. Testing the Safe Haven in Crisis Hypothesis

\begin{tabular}{|c|c|c|c|c|c|c|c|c|c|}
\hline \multicolumn{10}{|c|}{ Panel B: Specific features of the deposit insurance scheme } \\
\hline & (1) & (2) & (3) & (4) & (5) & (6) & (7) & (8) & (9) \\
\hline \multirow[t]{2}{*}{ Coverage ratio $*$ Stable } & $0.05^{*}$ & & & & & & & & \\
\hline & $(1.77)$ & & & & & & & & \\
\hline \multirow[t]{2}{*}{ Coverage ratio $*$ Crisis } & $0.09 * * *$ & & & & & & & & \\
\hline & (2.89) & & & & & & & & \\
\hline \multirow[t]{2}{*}{ Limit per person * Stable } & & -0.02 & & & & & & & \\
\hline & & $(-0.77)$ & & & & & & & \\
\hline \multirow[t]{2}{*}{ Limit per person ${ }^{*}$ Crisis } & & 0.04 & & & & & & & \\
\hline & & (1.19) & & & & & & & \\
\hline \multirow[t]{2}{*}{ Coinsurance * Stable } & & & $-0.05^{* *}$ & & & & & & \\
\hline & & & $(-1.98)$ & & & & & & \\
\hline \multirow[t]{2}{*}{ Coinsurance $*$ Crisis } & & & 0.05 & & & & & & \\
\hline & & & $(0.53)$ & & & & & & \\
\hline \multirow[t]{2}{*}{ Foreign currency coverage $*$ Stable } & & & & 0.02 & & & & & \\
\hline & & & & $(0.72)$ & & & & & \\
\hline \multirow[t]{2}{*}{ Foreign currency coverage $*$ Crisis } & & & & 0.07 & & & & & \\
\hline & & & & $(1.05)$ & & & & & \\
\hline \multirow[t]{2}{*}{ Additional compensation * Stable } & & & & & $0.05^{* * *}$ & & & & \\
\hline & & & & & (2.63) & & & & \\
\hline \multirow[t]{2}{*}{ Additional compensation * Crisis } & & & & & $0.16 * * *$ & & & & \\
\hline & & & & & (3.43) & & & & \\
\hline \multirow[t]{2}{*}{ Uninsured ratio * Stable } & & & & & & $-0.06 *$ & & & \\
\hline & & & & & & $(-1.81)$ & & & \\
\hline \multirow[t]{2}{*}{ Uninsured ratio * Crisis } & & & & & & 0.17 & & & \\
\hline & & & & & & $(1.43)$ & & & \\
\hline \multirow[t]{2}{*}{ Insured funding * Stable } & & & & & & & $0.01^{* * *}$ & & \\
\hline & & & & & & & (3.66) & & \\
\hline \multirow[t]{2}{*}{ Insured funding * Crisis } & & & & & & & $0.01^{* * *}$ & & \\
\hline & & & & & & & (2.88) & & \\
\hline \multirow[t]{2}{*}{ Funding source index $*$ Stable } & & & & & & & & $-0.04^{* *}$ & \\
\hline & & & & & & & & $(-2.07)$ & \\
\hline \multirow[t]{2}{*}{ Funding source index * Crisis } & & & & & & & & 0.02 & \\
\hline & & & & & & & & $(0.76)$ & \\
\hline \multirow[t]{2}{*}{ Compulsory participation * Stable } & & & & & & & & & 0.01 \\
\hline & & & & & & & & & $(0.28)$ \\
\hline \multirow[t]{2}{*}{ Compulsory participation * Crisis } & & & & & & & & & 0.09 \\
\hline & & & & & & & & & $(1.28)$ \\
\hline \multirow[t]{2}{*}{ Size } & $0.10^{* * *}$ & 0.01 & 0.02 & $0.02 *$ & $0.02 * *$ & $0.04^{* *}$ & 0.01 & 0.01 & $0.03 * *$ \\
\hline & (2.88) & $(1.30)$ & (1.54) & $(1.74)$ & $(2.00)$ & $(2.48)$ & (0.59) & $(0.50)$ & $(2.05)$ \\
\hline Bank country fixed effect & Yes & Yes & Yes & Yes & Yes & Yes & Yes & Yes & Yes \\
\hline Depositor country fixed effect & Yes & Yes & Yes & Yes & Yes & Yes & Yes & Yes & Yes \\
\hline Country-pair fixed effect & Yes & Yes & Yes & Yes & Yes & Yes & Yes & Yes & Yes \\
\hline Year fixed effect & Yes & Yes & Yes & Yes & Yes & Yes & Yes & Yes & Yes \\
\hline Adjusted R-squared & 0.966 & 0.947 & 0.955 & 0.955 & 0.948 & 0.958 & 0.938 & 0.943 & 0.953 \\
\hline Observations & 12,980 & 21,575 & 12,591 & 13,207 & 16,465 & 7,951 & 8,417 & 21,491 & 13,097 \\
\hline
\end{tabular}


Table 3. Testing the Safe Haven in Crisis Hypothesis

\begin{tabular}{|c|c|c|c|c|c|c|c|c|c|}
\hline & (10) & $(11)$ & (12) & (13) & (14) & (15) & (16) & (17) & (18) \\
\hline \multirow[t]{2}{*}{ Coverage ratio $*$ Stable } & 0.04 & & & & & & & & \\
\hline & $(1.26)$ & & & & & & & & \\
\hline \multirow[t]{2}{*}{ Coverage ratio $*$ Crisis } & $0.08 * * *$ & & & & & & & & \\
\hline & $(2.68)$ & & & & & & & & \\
\hline \multirow[t]{2}{*}{ Limit per person * Stable } & & -0.03 & & & & & & & \\
\hline & & $(-1.25)$ & & & & & & & \\
\hline \multirow[t]{2}{*}{ Limit per person * Crisis } & & 0.04 & & & & & & & \\
\hline & & $(1.03)$ & & & & & & & \\
\hline \multirow[t]{2}{*}{ Coinsurance * Stable } & & & $-0.06^{* *}$ & & & & & & \\
\hline & & & $(-2.22)$ & & & & & & \\
\hline \multirow[t]{2}{*}{ Coinsurance $*$ Crisis } & & & 0.04 & & & & & & \\
\hline & & & $(0.44)$ & & & & & & \\
\hline \multirow[t]{2}{*}{ Foreign currency coverage * Stable } & & & & 0.01 & & & & & \\
\hline & & & & $(0.38)$ & & & & & \\
\hline \multirow[t]{2}{*}{ Foreign currency coverage ${ }^{*}$ Crisis } & & & & 0.06 & & & & & \\
\hline & & & & (0.99) & & & & & \\
\hline \multirow[t]{2}{*}{ Additional compensation * Stable } & & & & & $0.07^{* * *}$ & & & & \\
\hline & & & & & (4.14) & & & & \\
\hline \multirow[t]{2}{*}{ Additional compensation * Crisis } & & & & & $0.20 * * *$ & & & & \\
\hline & & & & & $(4.35)$ & & & & \\
\hline \multirow[t]{2}{*}{ Uninsured ratio * Stable } & & & & & & -0.05 & & & \\
\hline & & & & & & $(-1.39)$ & & & \\
\hline \multirow[t]{2}{*}{ Uninsured ratio * Crisis } & & & & & & 0.19 & & & \\
\hline & & & & & & $(1.60)$ & & & \\
\hline \multirow[t]{2}{*}{ Insured funding * Stable } & & & & & & & $0.01^{* * *}$ & & \\
\hline & & & & & & & (2.91) & & \\
\hline \multirow[t]{2}{*}{ Insured funding * Crisis } & & & & & & & $0.01^{* *}$ & & \\
\hline & & & & & & & $(2.40)$ & & \\
\hline \multirow[t]{2}{*}{ Funding source index $*$ Stable } & & & & & & & & -0.02 & \\
\hline & & & & & & & & $(-1.30)$ & \\
\hline \multirow[t]{2}{*}{ Funding source index * Crisis } & & & & & & & & 0.05 & \\
\hline & & & & & & & & $(1.53)$ & \\
\hline \multirow[t]{2}{*}{ Compulsory participation * Stable } & & & & & & & & & 0.00 \\
\hline & & & & & & & & & $(0.09)$ \\
\hline Compulsory participation * Crisis & & & & & & & & & 0.09 \\
\hline & & & & & & & & & $(1.26)$ \\
\hline Size & $0.10 * * *$ & 0.01 & 0.02 & 0.02 & $0.02 * *$ & $0.03 *$ & 0.01 & 0.01 & $0.02 *$ \\
\hline & (2.82) & $(1.33)$ & $(1.23)$ & $(1.45)$ & (2.12) & $(1.82)$ & $(0.46)$ & $(0.63)$ & (1.76) \\
\hline Credit & $-0.28 * * *$ & $-0.10 * * *$ & 0.04 & -0.00 & $-0.15 * * *$ & 0.04 & $-0.12^{*}$ & $-0.12 * * *$ & -0.01 \\
\hline & $(-10.54)$ & $(-4.99)$ & (1.14) & $(-0.09)$ & $(-6.46)$ & $(0.96)$ & $(-1.95)$ & $(-5.48)$ & $(-0.45)$ \\
\hline Trade & $0.01 *$ & $0.02 * * *$ & 0.02 & 0.02 & $0.02 * * *$ & $0.05^{* * *}$ & 0.02 & $0.02 * * *$ & 0.02 \\
\hline & (1.79) & $(4.05)$ & $(1.46)$ & $(1.43)$ & (3.44) & (3.77) & $(0.72)$ & (3.75) & $(1.37)$ \\
\hline Globalisation & 0.00 & $-0.01 * * *$ & $-0.01 * * *$ & $-0.01 * * *$ & $-0.01^{* *}$ & -0.00 & $-0.01^{* *}$ & $-0.01 * *$ & $-0.01 * * *$ \\
\hline & $(0.89)$ & $(-3.89)$ & $(-3.14)$ & $(-3.08)$ & $(-2.56)$ & $(-0.56)$ & $(-1.96)$ & $(-2.48)$ & $(-3.54)$ \\
\hline FTA & -0.08 & $0.17^{* * *}$ & $0.14^{* * *}$ & $0.16^{* * *}$ & $0.23 * * *$ & $0.23^{* * *}$ & 0.08 & $0.15^{* * *}$ & $0.17^{* * *}$ \\
\hline & $(-0.16)$ & (4.34) & (2.89) & (3.45) & (5.13) & (3.64) & (1.09) & (3.67) & (3.55) \\
\hline Currency union & $0.34 * * *$ & $0.32 * * *$ & -0.24 & -0.16 & $0.35^{* * *}$ & $0.22^{* * *}$ & 0.09 & $0.35^{* * *}$ & -0.16 \\
\hline & $(6.40)$ & (5.29) & $(-1.14)$ & $(-0.75)$ & (5.15) & (2.74) & $(0.27)$ & $(5.50)$ & $(-0.77)$ \\
\hline Bank country fixed effect & Yes & Yes & Yes & Yes & Yes & Yes & Yes & Yes & Yes \\
\hline Depositor country fixed effect & Yes & Yes & Yes & Yes & Yes & Yes & Yes & Yes & Yes \\
\hline Country-pair fixed effect & Yes & Yes & Yes & Yes & Yes & Yes & Yes & Yes & Yes \\
\hline Year fixed effect & Yes & Yes & Yes & Yes & Yes & Yes & Yes & Yes & Yes \\
\hline Adjusted R-squared & 0.967 & 0.947 & 0.955 & 0.955 & 0.948 & 0.958 & 0.938 & 0.943 & 0.953 \\
\hline Observations & 12,980 & 21,575 & 12,591 & 13,207 & 16,465 & 7,951 & 8,417 & 21,491 & 13,097 \\
\hline
\end{tabular}


Table 4. Testing the Regulatory Arbitrage in Crisis Hypothesis

\begin{tabular}{|c|c|c|c|c|c|c|}
\hline \multicolumn{7}{|c|}{ Panel A: Main features of the deposit insurance scheme } \\
\hline & $(1)$ & $(2)$ & (3) & (4) & (5) & (6) \\
\hline \multirow[t]{2}{*}{ Explicit DI * Stable } & $1.35 * * *$ & & & $1.09 * * *$ & & \\
\hline & $(25.84)$ & & & $(20.87)$ & & \\
\hline \multirow[t]{2}{*}{ Explicit DI * Crisis } & $0.76^{* * *}$ & & & $0.34 * *$ & & \\
\hline & $(5.41)$ & & & $(2.56)$ & & \\
\hline \multirow[t]{2}{*}{ DI power * Stable } & & $0.04 * * *$ & & & $0.04 * *$ & \\
\hline & & $(2.75)$ & & & $(2.52)$ & \\
\hline \multirow[t]{2}{*}{ DI power * Crisis } & & 0.02 & & & 0.01 & \\
\hline & & $(0.54)$ & & & $(0.32)$ & \\
\hline \multirow[t]{2}{*}{ DI moral hazard mitigation * Stable } & & & 0.03 & & & 0.03 \\
\hline & & & $(1.44)$ & & & $(1.41)$ \\
\hline \multirow[t]{2}{*}{ DI moral hazard mitigation * Crisis } & & & -0.04 & & & -0.02 \\
\hline & & & $(-0.55)$ & & & $(-0.35)$ \\
\hline \multirow[t]{2}{*}{ Size } & $0.37^{* * *}$ & 0.08 & $0.26 * * *$ & $0.35 * * *$ & 0.04 & $0.29 * * *$ \\
\hline & $(33.40)$ & $(1.21)$ & (4.09) & $(29.14)$ & $(0.66)$ & (4.33) \\
\hline \multirow[t]{2}{*}{ Credit } & & & & $1.57 * * *$ & 0.06 & 0.00 \\
\hline & & & & $(37.48)$ & $(1.40)$ & $(0.03)$ \\
\hline \multirow[t]{2}{*}{ Trade } & & & & $0.05^{* * *}$ & 0.02 & -0.03 \\
\hline & & & & (8.97) & $(0.70)$ & $(-1.30)$ \\
\hline \multirow[t]{2}{*}{ Globalisation } & & & & $-0.01 * * *$ & $-0.01 * * *$ & $-0.01 * * *$ \\
\hline & & & & $(-5.43)$ & $(-3.20)$ & $(-3.03)$ \\
\hline \multirow[t]{2}{*}{ FTA } & & & & $0.61 * * *$ & $0.15 * * *$ & 0.02 \\
\hline & & & & (9.06) & (2.99) & $(0.41)$ \\
\hline \multirow[t]{2}{*}{ Currency union } & & & & $0.47^{* * *}$ & 0.10 & $0.23 *$ \\
\hline & & & & $(5.00)$ & $(0.89)$ & (1.94) \\
\hline Bank country fixed effect & No & Yes & Yes & No & Yes & Yes \\
\hline Depositor country fixed effect & Yes & Yes & Yes & Yes & Yes & Yes \\
\hline Country-pair fixed effect & No & Yes & Yes & No & Yes & Yes \\
\hline Year fixed effect & Yes & Yes & Yes & Yes & Yes & Yes \\
\hline Adjusted R-squared & 0.444 & 0.949 & 0.952 & 0.499 & 0.949 & 0.952 \\
\hline Observations & 18,525 & 7,076 & 6,808 & 18,525 & 7,076 & 6,808 \\
\hline
\end{tabular}


Table 4. Testing the Regulatory Arbitrage in Crisis Hypothesis

\begin{tabular}{|c|c|c|c|c|c|c|c|c|c|}
\hline & (1) & (2) & (3) & (4) & (5) & (6) & (7) & (8) & (9) \\
\hline \multirow[t]{2}{*}{ Coverage ratio $*$ Stable } & -0.00 & & & & & & & & \\
\hline & $(-0.16)$ & & & & & & & & \\
\hline \multirow[t]{2}{*}{ Coverage ratio $*$ Crisis } & -0.01 & & & & & & & & \\
\hline & $(-0.45)$ & & & & & & & & \\
\hline \multirow[t]{2}{*}{ Limit per person * Stable } & & -0.03 & & & & & & & \\
\hline & & $(-1.18)$ & & & & & & & \\
\hline \multirow[t]{2}{*}{ Limit per person * Crisis } & & -0.08 & & & & & & & \\
\hline & & $(-1.29)$ & & & & & & & \\
\hline \multirow[t]{2}{*}{ Coinsurance * Stable } & & & -0.02 & & & & & & \\
\hline & & & $(-0.81)$ & & & & & & \\
\hline \multirow[t]{2}{*}{ Coinsurance $*$ Crisis } & & & -0.07 & & & & & & \\
\hline & & & $(-0.61)$ & & & & & & \\
\hline \multirow[t]{2}{*}{ Foreign currency coverage $*$ Stable } & & & & -0.02 & & & & & \\
\hline & & & & $(-0.65)$ & & & & & \\
\hline \multirow[t]{2}{*}{ Foreign currency coverage $*$ Crisis } & & & & -0.10 & & & & & \\
\hline & & & & $(-0.43)$ & & & & & \\
\hline \multirow[t]{2}{*}{ Additional compensation * Stable } & & & & & $0.06^{* * *}$ & & & & \\
\hline & & & & & $(2.62)$ & & & & \\
\hline \multirow[t]{2}{*}{ Additional compensation * Crisis } & & & & & 0.03 & & & & \\
\hline & & & & & $(0.50)$ & & & & \\
\hline \multirow[t]{2}{*}{ Uninsured ratio * Stable } & & & & & & -0.07 & & & \\
\hline & & & & & & $(-1.22)$ & & & \\
\hline \multirow[t]{2}{*}{ Uninsured ratio * Crisis } & & & & & & 0.08 & & & \\
\hline & & & & & & $(0.35)$ & & & \\
\hline \multirow[t]{2}{*}{ Insured funding * Stable } & & & & & & & $0.00^{*}$ & & \\
\hline & & & & & & & (1.92) & & \\
\hline \multirow[t]{2}{*}{ Insured funding * Crisis } & & & & & & & 0.01 & & \\
\hline & & & & & & & (1.27) & & \\
\hline \multirow[t]{2}{*}{ Funding source index $*$ Stable } & & & & & & & & $-0.07^{* * *}$ & \\
\hline & & & & & & & & $(-3.82)$ & \\
\hline \multirow[t]{2}{*}{ Funding source index $*$ Crisis } & & & & & & & & -0.06 & \\
\hline & & & & & & & & $(-1.16)$ & \\
\hline \multirow[t]{2}{*}{ Compulsory participation * Stable } & & & & & & & & & 0.04 \\
\hline & & & & & & & & & $(0.84)$ \\
\hline \multirow[t]{2}{*}{ Compulsory participation * Crisis } & & & & & & & & & -0.28 \\
\hline & & & & & & & & & $(-0.85)$ \\
\hline \multirow[t]{2}{*}{ Size } & $0.16^{* * *}$ & $0.24 * * *$ & $0.25^{* * *}$ & $0.24^{* * *}$ & $0.22^{* * *}$ & $0.55^{* * *}$ & 0.02 & $0.21 * * *$ & $0.30 * * *$ \\
\hline & $(2.63)$ & $(5.48)$ & (3.01) & (3.23) & $(4.35)$ & $(5.24)$ & $(0.17)$ & (4.59) & (4.49) \\
\hline Bank country fixed effect & Yes & Yes & Yes & Yes & Yes & Yes & Yes & Yes & Yes \\
\hline Depositor country fixed effect & Yes & Yes & Yes & Yes & Yes & Yes & Yes & Yes & Yes \\
\hline Country-pair fixed effect & Yes & Yes & Yes & Yes & Yes & Yes & Yes & Yes & Yes \\
\hline Year fixed effect & Yes & Yes & Yes & Yes & Yes & Yes & Yes & Yes & Yes \\
\hline Adjusted R-squared & 0.970 & 0.947 & 0.951 & 0.952 & 0.956 & 0.972 & 0.943 & 0.945 & 0.951 \\
\hline Observations & 5,461 & 9,902 & 5,906 & 6,638 & 6,443 & 2,108 & 4,299 & 9,900 & 6,893 \\
\hline
\end{tabular}


Table 4. Testing the Regulatory Arbitrage in Crisis Hypothesis

\begin{tabular}{|c|c|c|c|c|c|c|c|c|c|}
\hline & (10) & (11) & (12) & (13) & (14) & (15) & (16) & (17) & (18) \\
\hline \multirow[t]{2}{*}{ Coverage ratio $*$ Stable } & -0.00 & & & & & & & & \\
\hline & $(-0.23)$ & & & & & & & & \\
\hline \multirow[t]{2}{*}{ Coverage ratio $*$ Crisis } & -0.01 & & & & & & & & \\
\hline & $(-0.46)$ & & & & & & & & \\
\hline \multirow[t]{2}{*}{ Limit per person * Stable } & & -0.05 & & & & & & & \\
\hline & & $(-1.60)$ & & & & & & & \\
\hline \multirow[t]{2}{*}{ Limit per person * Crisis } & & -0.07 & & & & & & & \\
\hline & & $(-1.10)$ & & & & & & & \\
\hline \multirow[t]{2}{*}{ Coinsurance * Stable } & & & -0.01 & & & & & & \\
\hline & & & $(-0.44)$ & & & & & & \\
\hline \multirow[t]{2}{*}{ Coinsurance * Crisis } & & & -0.04 & & & & & & \\
\hline & & & $(-0.38)$ & & & & & & \\
\hline \multirow[t]{2}{*}{ Foreign currency coverage * Stable } & & & & -0.04 & & & & & \\
\hline & & & & $(-0.99)$ & & & & & \\
\hline \multirow[t]{2}{*}{ Foreign currency coverage $*$ Crisis } & & & & -0.13 & & & & & \\
\hline & & & & $(-0.52)$ & & & & & \\
\hline \multirow[t]{2}{*}{ Additional compensation * Stable } & & & & & $0.07^{* * *}$ & & & & \\
\hline & & & & & $(2.94)$ & & & & \\
\hline \multirow[t]{2}{*}{ Additional compensation * Crisis } & & & & & 0.04 & & & & \\
\hline & & & & & $(0.62)$ & & & & \\
\hline \multirow[t]{2}{*}{ Uninsured ratio * Stable } & & & & & & -0.07 & & & \\
\hline & & & & & & $(-1.24)$ & & & \\
\hline \multirow[t]{2}{*}{ Uninsured ratio * Crisis } & & & & & & 0.15 & & & \\
\hline & & & & & & $(0.62)$ & & & \\
\hline \multirow[t]{2}{*}{ Insured funding * Stable } & & & & & & & 0.00 & & \\
\hline & & & & & & & (1.56) & & \\
\hline \multirow[t]{2}{*}{ Insured funding * Crisis } & & & & & & & 0.01 & & \\
\hline & & & & & & & $(1.22)$ & & \\
\hline \multirow[t]{2}{*}{ Funding source index * Stable } & & & & & & & & $-0.06^{* * *}$ & \\
\hline & & & & & & & & $(-3.51)$ & \\
\hline \multirow[t]{2}{*}{ Funding source index ${ }^{*}$ Crisis } & & & & & & & & -0.08 & \\
\hline & & & & & & & & $(-1.46)$ & \\
\hline \multirow[t]{2}{*}{ Compulsory participation * Stable } & & & & & & & & & 0.03 \\
\hline & & & & & & & & & $(0.65)$ \\
\hline Compulsory participation * Crisis & & & & & & & & & -0.30 \\
\hline & & & & & & & & & $(-0.93)$ \\
\hline Size & $0.16^{* * *}$ & $0.29 * * *$ & $0.22 * *$ & $0.21^{* * *}$ & $0.25 * * *$ & $0.58^{* * *}$ & 0.05 & $0.25^{* * *}$ & $0.30^{* * *}$ \\
\hline & $(2.72)$ & $(6.22)$ & $(2.55)$ & $(2.71)$ & $(4.72)$ & $(5.06)$ & $(0.45)$ & $(5.36)$ & (4.27) \\
\hline Credit & $-0.29 * * *$ & $-0.08^{* * *}$ & -0.02 & -0.04 & $-0.10 * *$ & -0.02 & $-0.22 * * *$ & $-0.10 * * *$ & -0.06 \\
\hline & $(-6.83)$ & $(-2.67)$ & $(-0.40)$ & $(-0.90)$ & $(-2.46)$ & $(-0.41)$ & $(-3.23)$ & $(-3.25)$ & $(-1.39)$ \\
\hline Trade & $0.01^{*}$ & $0.02 * *$ & 0.02 & 0.03 & 0.01 & -0.02 & -0.01 & $0.01 *$ & 0.01 \\
\hline & $(1.84)$ & $(2.19)$ & $(0.74)$ & $(1.10)$ & $(1.22)$ & $(-0.59)$ & $(-0.26)$ & $(1.74)$ & $(0.23)$ \\
\hline Globalisation & -0.01 & $-0.02 * * *$ & $-0.02 * * *$ & $-0.02 * * *$ & $-0.01 * * *$ & -0.01 & -0.00 & $-0.01 * * *$ & $-0.02 * * *$ \\
\hline & $(-1.33)$ & $(-5.00)$ & $(-3.40)$ & $(-3.49)$ & $(-2.80)$ & $(-1.21)$ & $(-0.23)$ & $(-3.32)$ & $(-4.39)$ \\
\hline FTA & -0.07 & 0.05 & $0.11^{*}$ & $0.13^{* *}$ & $0.12 * *$ & 0.01 & 0.03 & 0.01 & $0.15^{* * *}$ \\
\hline & $(-0.14)$ & (1.01) & $(1.88)$ & $(2.43)$ & $(2.28)$ & $(0.14)$ & $(0.38)$ & $(0.28)$ & (2.92) \\
\hline Currency union & $0.30^{* * *}$ & $0.30 * * *$ & -0.30 & -0.20 & $0.48^{* * *}$ & 0.00 & 0.01 & $0.32^{* * *}$ & -0.21 \\
\hline & $(5.01)$ & (4.28) & $(-1.29)$ & $(-0.91)$ & $(5.60)$ & $(0.00)$ & $(0.04)$ & $(4.47)$ & $(-0.94)$ \\
\hline Bank country fixed effect & Yes & Yes & Yes & Yes & Yes & Yes & Yes & Yes & Yes \\
\hline Depositor country fixed effect & Yes & Yes & Yes & Yes & Yes & Yes & Yes & Yes & Yes \\
\hline Country-pair fixed effect & Yes & Yes & Yes & Yes & Yes & Yes & Yes & Yes & Yes \\
\hline Year fixed effect & Yes & Yes & Yes & Yes & Yes & Yes & Yes & Yes & Yes \\
\hline Adjusted R-squared & 0.971 & 0.947 & 0.951 & 0.952 & 0.957 & 0.972 & 0.943 & 0.945 & 0.952 \\
\hline Observations & 5,461 & 9,902 & 5,906 & 6,638 & 6,443 & 2,108 & 4,299 & 9,900 & 6,893 \\
\hline
\end{tabular}

Note: This table presents the estimates from ordinary least square regressions of cross-border deposits from customer country $j$ to reporting country $i$ in year $t$. All variable definitions can be found in Table A1 in the Appendix. The coefficients are reported in the top row, $\mathrm{t}$-values are reported below in brackets. ${ }^{*},{ }^{* *},{ }^{* * *}$ represent statistical significance at the $10 \%, 5 \%$ and $1 \%$ level, respectively. 
Sample period 1998-2011

Explicit DI Introduction *2008/09 Crisis Period Official government guarantee *2008/09 Crisis Period Limited government guarantee *2008/09 Crisis Period Unlimited government guarantee *2008/09 Crisis Period Size

\begin{tabular}{r} 
All bank cou \\
\hline$(1)$ \\
$0.54^{* * *}$
\end{tabular}
(4) $0.23 * * *$

$$
\text { (9.75) }
$$

$$
\begin{array}{r}
0.27^{* * *} \\
(8.49)
\end{array}
$$
$0.20 * * *$ (7.08) $0.06^{* * *} 0.08^{* * *} \quad 0.09 * * * \quad 0.11 * * *$
Sample period 2006-2009

Bank countries in crisis
(5) (6)

$0.22 * * *$

(9.00)

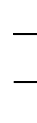

All bank countries

$(8)$
$0.17^{* *}$
$(2.39)$

(9) (10) (11) Bank count

untri

tries in crisis

$0.11^{* * *}$

$$
\text { (3.86) }
$$

$0.11 * * *$

(3.00)

(3.14)

0.08

$0.10 *$

0.10*

(1.76)

$0.13^{* *}$

$0.10 * * *$

(3.39)

$0.12 * * *$

(3.12) $0.29 * * *$

(9.10)

\begin{tabular}{|c|c|c|}
\hline & $\begin{array}{r}0.29 * * * \\
(9.10)\end{array}$ & \\
\hline & & $\begin{array}{r}0.16 * * * \\
(5.36)\end{array}$ \\
\hline $0.11 * * *$ & $0.13 * * *$ & $0.16 * * *$ \\
\hline (4.91) & (5.37) & (6.77) \\
\hline
\end{tabular}
$0.16^{* * *}$

(5.36) $0.11^{* * *} 0.13^{* * *} 0.16 * * *$

\section{Bank country fixed effect}

Depositor country fixed effect

Country-pair fixed effect

Year fixed effect

Adjusted R-squared

$\begin{array}{cccc}\text { Yes } & \text { Yes } & \text { Yes } & \text { Yes } \\ \text { Yes } & \text { Yes } & \text { Yes } & \text { Yes } \\ \text { Yes } & \text { Yes } & \text { Yes } & \text { Yes } \\ \text { Yes } & \text { Yes } & \text { Yes } & \text { Yes }\end{array}$

\begin{tabular}{rrrrrrrrrrrrrr} 
Yes & Yes & Yes & Yes & Yes & Yes & Yes & Yes & Yes & Yes & Yes & Yes & Yes & Yes \\
Yes & Yes & Yes & Yes & Yes & Yes & Yes & Yes & Yes & Yes & Yes & Yes & Yes & Yes \\
Yes & Yes & Yes & Yes & Yes & Yes & Yes & Yes & Yes & Yes & Yes & Yes & Yes & Yes \\
Yes & Yes & Yes & Yes & Yes & Yes & Yes & Yes & Yes & Yes & Yes & Yes & Yes & Yes \\
& & & & & & & & & & & & & \\
0.925 & 0.925 & 0.932 & 0.927 & 0.927 & 0.932 & 0.932 & 0.951 & 0.951 & 0.958 & 0.952 & 0.954 & 0.960 & 0.956 \\
31,115 & 31,115 & 25,420 & 28,037 & 26,407 & 21,944 & 23,329 & 11,656 & 11,656 & 9,726 & 10,551 & 9,608 & 8,125 & 8,503 \\
\hline
\end{tabular}

$0.11 * * *$

$0.09 * *$

(2.41)

$0.18^{* * *} 0.17 * * * 0.22 * * *$

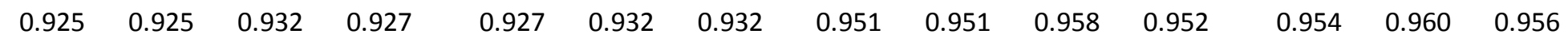

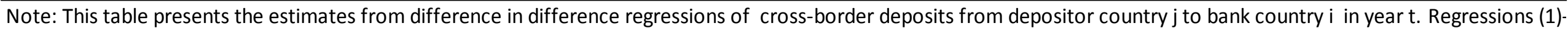

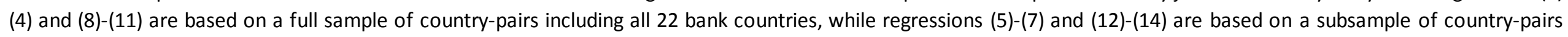

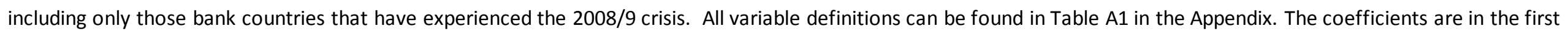
row, the t-values are below in brackets. ${ }^{*}, *, * * *$ represent statistical significance at the $10 \%, 5 \%$ and $1 \%$ level, respectively. 
Table A1. Variable definitions and sources

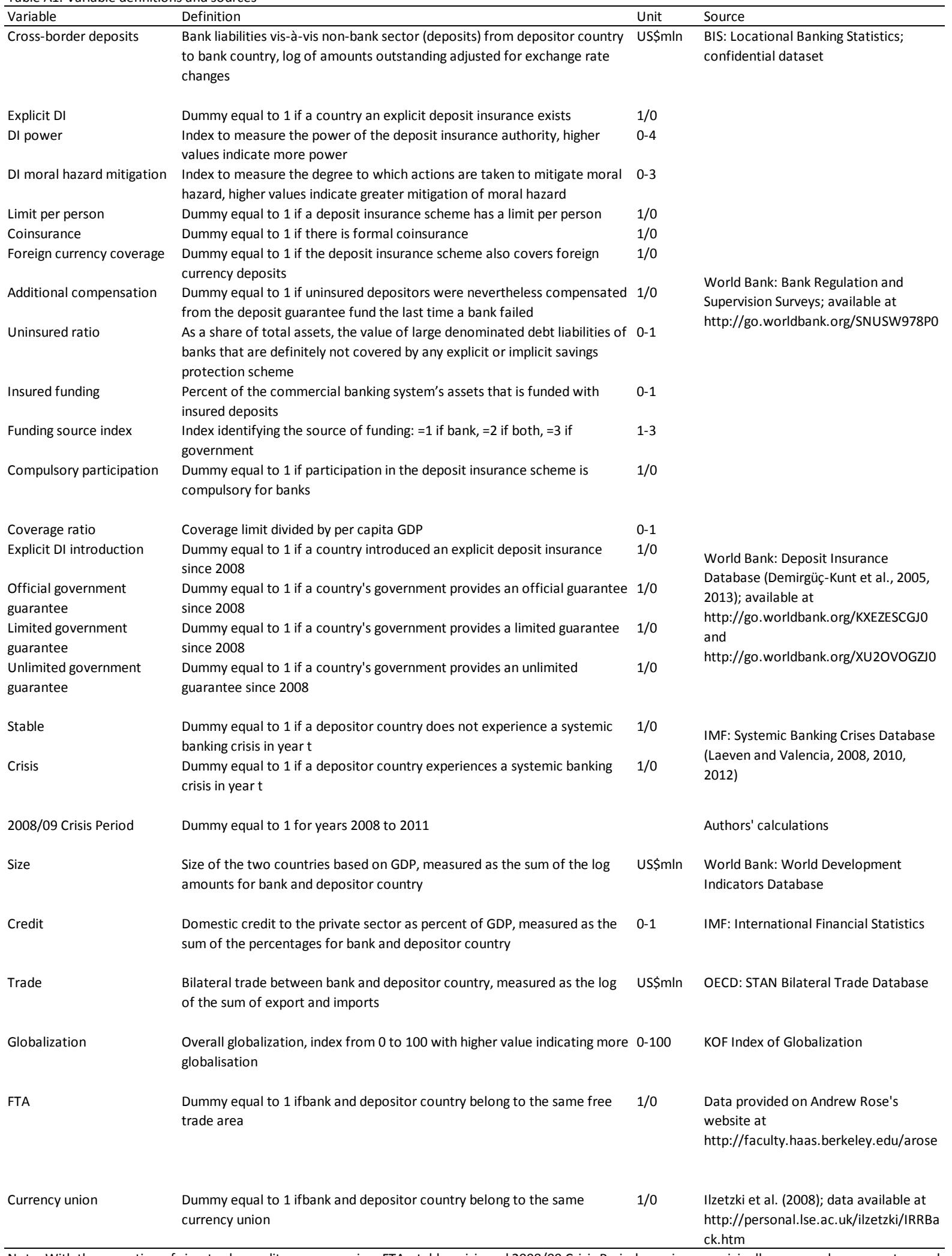

Note: With the exception of size, trade, credit, currency union, FTA, stable, crisis and 2008/09 Crisis Period, proxies are originally measured on a country- and year-level. For the Safe Haven analyses, the proxies for the bank country are used, e.g. Proxy ${ }_{i t}$. For the Regulatory Arbitrage analyses, the difference between the bank and depositor country is used, e.g. Proxy ${ }_{i j t}=\operatorname{Proxy}_{i t}-\operatorname{Proxy}_{j \mathrm{jt}}$. 
Table A2. Summary statistics

\begin{tabular}{lrrrrr}
\hline Variable & Obs & Mean & Std. Dev. & Min & Max \\
\hline Cross-border deposits & 24,103 & 2.77 & 2.70 & 0 & 13.13 \\
& & & & & \\
Bank country & & & & & \\
\hline Explicit DI & 23,487 & 0.92 & 0.26 & 0.00 & 1.00 \\
DI power & 15,923 & 1.42 & 0.89 & 0.00 & 4.00 \\
DI moral hazard mitigation & 17,809 & 1.56 & 0.71 & 0.00 & 3.00 \\
Coverage ratio & 12,980 & 1.52 & 1.31 & 0.34 & 5.54 \\
Limit per person & 21,575 & 0.93 & 0.26 & 0.00 & 1.00 \\
Coinsurance & 12,591 & 0.33 & 0.47 & 0.00 & 1.00 \\
Foreign currency coverage & 13,207 & 0.88 & 0.32 & 0.00 & 1.00 \\
Additional compensation & 16,465 & 0.34 & 0.47 & 0.00 & 1.00 \\
Uninsured ratio & 7,951 & 0.29 & 0.28 & 0.00 & 0.94 \\
Insured funding & 8,417 & 29.66 & 28.77 & 0.00 & 100.00 \\
Funding source index & 21,491 & 1.10 & 0.40 & 1.00 & 3.00 \\
Compulsory participation & 13,097 & 0.94 & 0.24 & 0.00 & 1.00
\end{tabular}

Country-pair differences

\begin{tabular}{lrrrrr}
\hline Explicit DI & 18,525 & 0.33 & 0.57 & -1.00 & 1.00 \\
DI power & 7,076 & 0.23 & 1.49 & -4.00 & 4.00 \\
DI moral hazard mitigation & 6,808 & 0.13 & 1.12 & -3.00 & 3.00 \\
Coverage ratio & 5,461 & -1.20 & 3.30 & -27.14 & 5.28 \\
Limit per person & 9,902 & 0.06 & 0.43 & -1.00 & 1.00 \\
Coinsurance & 5,906 & -0.12 & 0.69 & -1.00 & 1.00 \\
Foreign currency coverage & 6,638 & 0.09 & 0.52 & -1.00 & 1.00 \\
Additional compensation & 6,443 & -0.03 & 0.67 & -1.00 & 1.00 \\
Uninsured ratio & 2,108 & 0.00 & 0.41 & -1.00 & 0.94 \\
Insured funding & 4,299 & 6.49 & 39.87 & -100.00 & 100.00 \\
Funding source index & 9,900 & -0.26 & 0.76 & -2.00 & 2.00 \\
Compulsory participation & 6,893 & 0.05 & 0.39 & -1.00 & 1.00 \\
& & & & & \\
Size & 24,103 & 23.00 & 3.28 & 8.98 & 31.78 \\
Credit & 24,103 & 1.54 & 0.59 & 0.28 & 5.06 \\
Trade & 24,103 & 4.87 & 3.72 & 0.00 & 18.81 \\
Globalisation & 24,103 & 139.54 & 25.04 & 46.26 & 186.10 \\
FTA & 24,103 & 0.10 & 0.29 & 0.00 & 1.00 \\
Currency union & 24,103 & 0.04 & 0.20 & 0.00 & 1.00 \\
& & & & & \\
Explicit DI Introduction & 39,278 & 0.04 & 0.20 & 0.00 & 1.00 \\
Official government guarantee & 39,278 & 0.26 & 0.44 & 0.00 & 1.00 \\
Limited government guarantee & 39,278 & 0.08 & 0.28 & 0.00 & 1.00 \\
Unlimited government guarantee & 39,278 & 0.18 & 0.38 & 0.00 & 1.00 \\
\hline
\end{tabular}


Table A3. Systemic banking crises

Number of

\begin{tabular}{rr} 
Year & countries in crisis \\
\hline 1998 & 24
\end{tabular}

$1999 \quad 14$

$2000 \quad 10$

$2001 \quad 8$

20024

2003

20042

$2005 \quad 1$

$2006 \quad 0$

$2007 \quad 2$

$2008 \quad 23$

$2009 \quad 24$

$2010 \quad 24$

2011

24

Note: Borderline systemic banking crises are included. 
Table A4. Robustness checks regarding the test of the Safe Haven Hypothesis

\begin{tabular}{|c|c|c|c|c|c|c|}
\hline & (1) & (2) & (3) & (4) & (5) & (6) \\
\hline \multirow[t]{2}{*}{ Explicit DI $\mathrm{t}_{-1}$} & $1.75^{* * *}$ & & & $1.52 * * *$ & & \\
\hline & (31.66) & & & $(26.92)$ & & \\
\hline \multirow[t]{2}{*}{ DI power ${ }_{t-1}$} & & $0.04 * *$ & & & $0.04 * *$ & \\
\hline & & $(2.30)$ & & & $(2.30)$ & \\
\hline \multirow[t]{2}{*}{ DI moral hazard mitigation $\mathrm{t}_{\mathrm{t}-1}$} & & & $-0.05 * *$ & & & -0.04 \\
\hline & & & $(-2.01)$ & & & $(-1.56)$ \\
\hline \multirow[t]{2}{*}{ Size } & $0.31 * * *$ & 0.01 & 0.01 & $0.29 * * *$ & 0.00 & 0.01 \\
\hline & $(30.85)$ & $(0.63)$ & $(0.96)$ & $(26.28)$ & $(0.19)$ & (0.89) \\
\hline \multirow[t]{2}{*}{ Credit } & & & & $1.50 * * *$ & $0.07 * *$ & $-0.09 * * *$ \\
\hline & & & & $(37.84)$ & $(2.06)$ & $(-3.10)$ \\
\hline \multirow[t]{2}{*}{ Trade } & & & & $0.06 * * *$ & 0.02 & 0.02 \\
\hline & & & & $(9.86)$ & (1.17) & $(1.34)$ \\
\hline \multirow[t]{2}{*}{ Globalisation } & & & & $-0.02 * * *$ & $-0.01 * * *$ & $-0.01 * * *$ \\
\hline & & & & $(-9.46)$ & $(-3.85)$ & $(-3.40)$ \\
\hline \multirow[t]{2}{*}{ FTA } & & & & $0.48^{* * *}$ & $0.24 * * *$ & $0.14 * * *$ \\
\hline & & & & (7.04) & $(4.78)$ & $(2.98)$ \\
\hline \multirow[t]{2}{*}{ Currency union } & & & & $0.58 * * *$ & -0.07 & -0.02 \\
\hline & & & & $(6.22)$ & $(-0.44)$ & $(-0.18)$ \\
\hline Bank country fixed effect & No & Yes & Yes & No & Yes & Yes \\
\hline Depositor country fixed effect & Yes & Yes & Yes & Yes & Yes & Yes \\
\hline Country-pair fixed effect & No & Yes & Yes & No & Yes & Yes \\
\hline Year fixed effect & Yes & Yes & Yes & Yes & Yes & Yes \\
\hline Adjusted R-squared & 0.453 & 0.948 & 0.949 & 0.499 & 0.948 & 0.949 \\
\hline Observations & 20,787 & 13,859 & 15,518 & 20,787 & 13,859 & 15,518 \\
\hline
\end{tabular}

Note: This table presents the estimates from ordinary least square regressions of cross-border deposits from customer country $j$ to reporting country $i$ in year $t$. All variable definitions can be found in Table A1 in the Appendix. The coefficients are reported in the top row, t-values are reported below in brackets. $*, * *$, $* * *$ represent statistical significance at the $10 \%, 5 \%$ and $1 \%$ level, respectively. 
Table A5. Robustness checks regarding the test of the Regulatory Arbitrage Hypothesis

$\begin{array}{llll}(1) & \text { (2) }\end{array}$

(4)

(6)

Explicit $\mathrm{DI}_{\mathrm{t}-1}$

(19.67)

DI power ${ }_{\mathrm{t}-1}$

0.03*

$0.03^{*}$

DI moral hazard mitigation $\mathrm{n}_{\mathrm{t}-1}$

$\begin{array}{ll}-0.01 & -0.01\end{array}$

$(-0.27) \quad(-0.21)$

Size

$0.37 * * *$

0.11

$0.24 * * *$

$0.35 * * * \quad 0.08$

$0.27 * * *$

(30.84)

(1.54)

(3.30)

(26.83)

(1.08)

(3.50)

Credit

$1.52 * * *$

0.06

0.03

Trade

(33.56)

(1.25)

(0.69)

$0.06 * * *$

0.00

$-0.04$

Globalisation

(8.90) (0.01) (-1.44)

$-0.01 * * * \quad-0.02 * * * \quad-0.01 * *$

$\begin{array}{lll}(-5.27) & (-3.00) & (-2.37)\end{array}$

FTA

$0.50 * * * \quad 0.17 * * * \quad 0.07$

(6.91) (2.90) (1.02)

Currency union

$0.54 * * * \quad-0.10$

$-0.19$

(5.36) $(-0.64) \quad(-0.80)$

Bank country fixed effect

Depositor country fixed effect

No

Yes

Yes

Yes

Yes

Yes

Yes Yes

Yes

Yes

Yes

Yes

Country-pair fixed effect

No

Yes

Yes

Yes

Yes

Yes

Yes

Yes

Yes

Yes

Yes

\begin{tabular}{lrrrrrr} 
Adjusted R-squared & 0.446 & 0.952 & 0.954 & 0.496 & 0.952 & 0.954 \\
Observations & 16,299 & 6,127 & 5,759 & 16,299 & 6,127 & 5,759 \\
\hline
\end{tabular}

Note: This table presents the estimates from ordinary least square regressions of cross-border deposits from customer country $j$ to reporting country $i$ in year $t$. All variable definitions can be found in Table A1 in the Appendix. The coefficients are reported in the top row, t-values are reported below in brackets. $*, * *$, $* * *$ represent statistical significance at the $10 \%, 5 \%$ and $1 \%$ level, respectively. 
Figure 1. Cross-border deposits over time

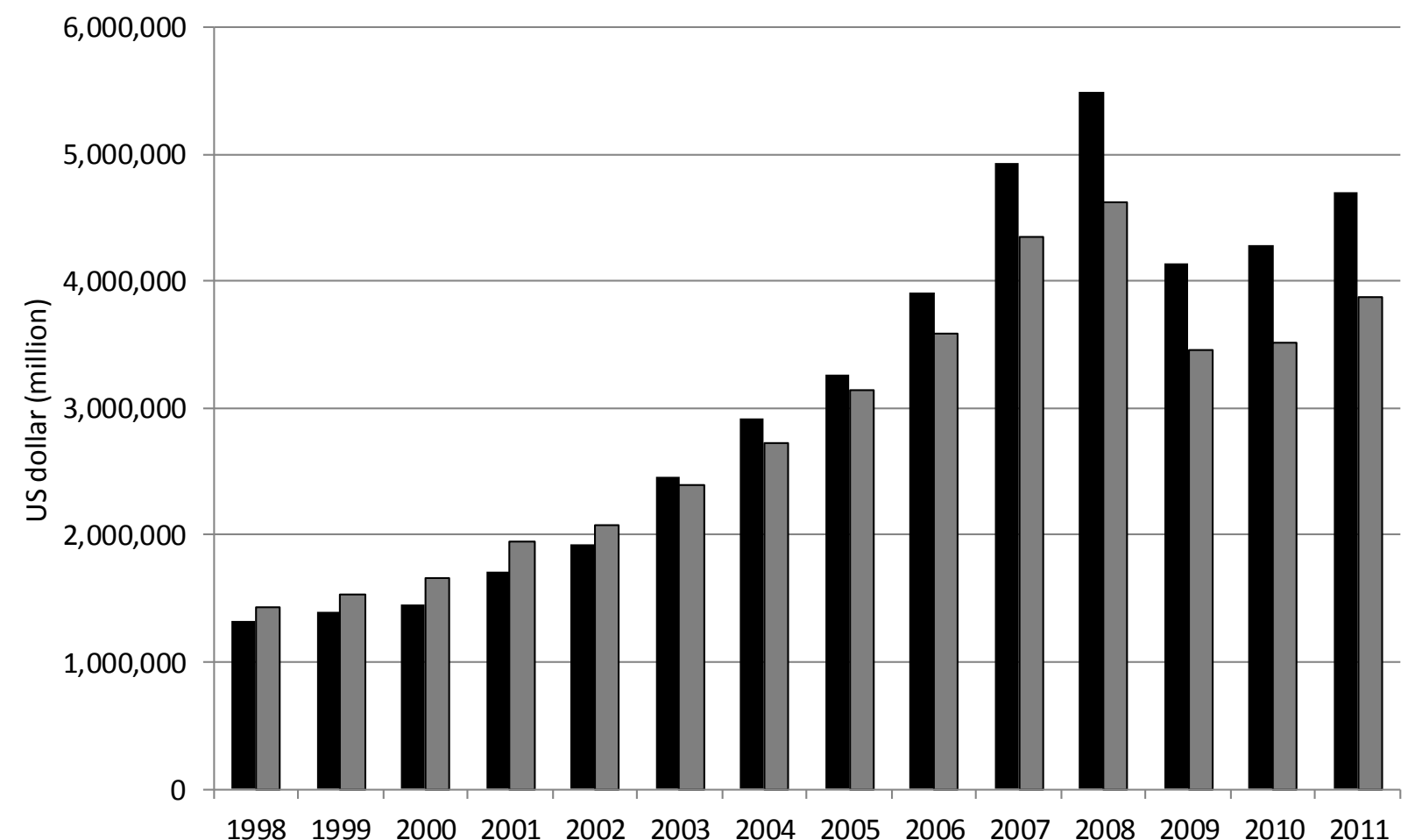

Note: This figure shows the total amount of cross-border deposits (CBD) between all 24 bank countries and all 168 depositor countries in our sample. Black bars represent unadjusted volumes of $C B D$, grey bars represent $C B D$ volumes that are adjusted for exchange rate movements. 
Figure 2. Cross-border deposit volumes for different bank countries

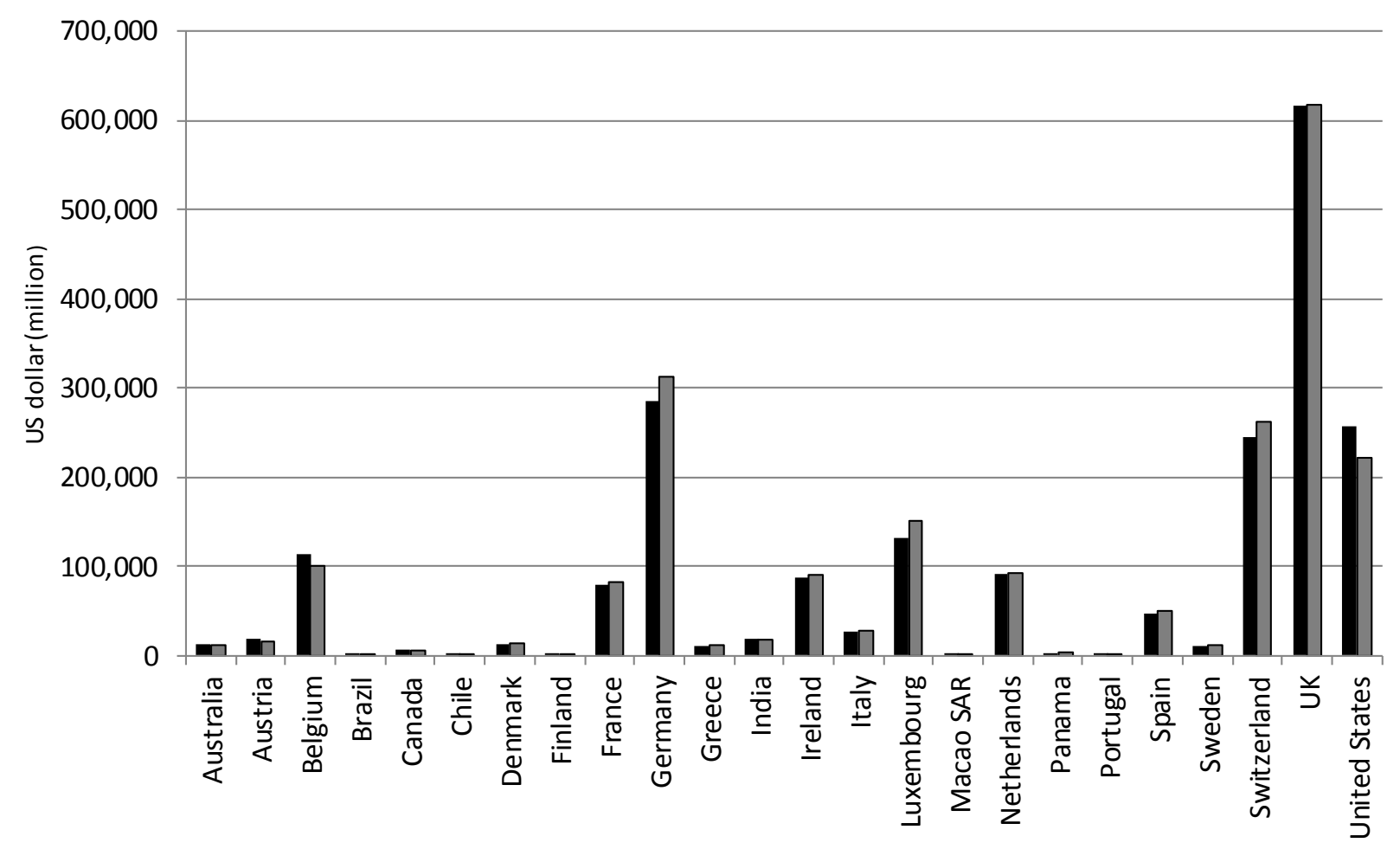

Note: This figure shows the average annual volume of cross-border deposits (CBD) that each of the 24 bank countries in our sample receives from all 168 depositor countries. Black bars represent unadjusted volumes of CBD, grey bars represent $\mathrm{CBD}$ volumes that are adjusted for exchange rate movements. 